\title{
The Role of Public-Private Partnerships and Collective Action in Ensuring Smallholder Participation in High Value Fruit and Vegetable Supply Chains
}

Clare Narrod and Devesh Roy, International Food Policy Research Institute, Julius Okello, University of Nairobi, Belem Avendaño, Universidad Autónoma de Baja California, Karl Rich, International Livestock Research Institute, and

Amit Thorat, Jawaharlal Nehru University

Research Workshop on Collective Action and Market Access for Smallholders October 2-5, 2006 - Cali, Colombia

The CGIAR Systemwide Program on Collective Action and Property Rights (CAPRi) is an initiative of the 15 centers that belong to the Consultative Group on International Agricultural Research. The initiative promotes comparative research on the role played by property rights and collective action institutions in shaping the efficiency, sustainability, and equity of natural resource systems. CAPRi's Secretariat is hosted by the International Food Policy Research Institute's (IFPRI) Environment and Production Technology Division (www.ifpri.org).

CAPRi Working Papers contain preliminary material and research results and are circulated prior to a full peer review in order to stimulate discussion and critical comment. It is expected that most Working Papers will eventually be published in some other form, and that their content may also be revised. http://dx.doi.org/10.2499/CAPRiWP70.

Copyright @ August 2007. International Food Policy Research Institute. All rights reserved. Sections of this material may be reproduced for personal and not-for-profit use without the express written permission of but with acknowledgment to IFPRI. To reproduce the material contained herein for profit or commercial use requires express written permission. To obtain permission to reprint, contact the IFPRI Communications Division at ifpri-copyright@cgiar.org.

CGIAR Systemwide Program on Collective Action and Property Rights (CAPRi) c/O INTERNATIONAL FOOD POLICY RESEARCH INSTITUTE

2033 K Street NW, Washington, DC 20006-1002 USA • T +1 202.862.5600 • F +1 202.467.4439 • www.capri.cgiar.org 


\begin{abstract}
Many developing countries have moved into the production of non-traditional agricultural products to diversify their exports and increase foreign currency earnings. Accessing developed country markets and urban domestic markets requires meeting the food safety requirements due to several demand and supply side factors. Food retailers have developed protocols relating to pesticide residues, field and packinghouse operations, and traceability. In this changing scenario where food safety requirements are getting increasingly stringent, there are worries regarding the livelihood of the poor since companies that establish production centers in LDCs might exclude them. Poor producers face problems of how to produce safe food, be recognized as producing safe food, identify cost-effective technologies for reducing risk, and be competitive with larger producers with advantage of economies of scale in compliance with food safety requirements. In enabling the smallholders to remain competitive in such a system, new institutional arrangements are required. In particular, public-private partnerships can play a key role in creating farm to fork linkages that can satisfy the market demands for food safety while retaining smallholders in the supply chain. Furthermore, organized producer groups monitoring their own food safety requirements through collective action often become attractive to buyers who are looking for ways to ensure traceability and reduce transaction costs. This paper compares how small producers of different fruit and vegetable products in different countries have coped with increased demands for food safety from their main export markets. These commodities are Kenyan green beans, Mexican cantaloupes, and Indian grapes.
\end{abstract}

Key words: food safety, supply chain management, public private partnerships, collective action, public and private standards, traceability 


\section{TABLE OF CONTENTS}

1. Introduction

2. Growth of the Supply of Fruits and Vegetables and the Response of LDCS ............................ 4

3. Development of Food Safety Standards and Regulations ...................................................... 6

4. Role of Supply Chains in the Delivery of Fruits and Vegetables ............................................ 8

5. Fruit and Vegetable Production and their Supply Chains from Three Case Studies................. 14

6. Difficulties Smallholders Have in Participating in these Supply Chains ................................ 26

7. Role of Various Institutions in Involving Smallholders in these Markets ................................ 29

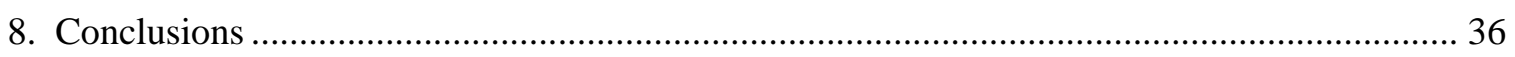

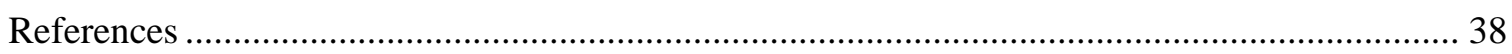




\title{
The Role of Public-Private Partnerships and Collective Action in Ensuring Smallholder Participation in High Value Fruit and Vegetable Supply Chains
}

\author{
Clare Narrod and Devesh Roy, ${ }_{1}^{1}$ Julius Okello, ${ }^{2}$ Belem Avendaño, ${ }^{3}$ \\ Karl Rich, ${ }^{4}$ and Amit Thorat ${ }^{5}$
}

\section{INTRODUCTION}

Many countries in Africa, Asia, and Latin America have moved into the production of non-traditional agricultural products to diversify their agricultural exports and increase foreign exchange earnings. High altitude regions in a number of African and Latin American countries enable the growth of cool season crops year round, providing an opportunity to export these products to developed countries. Similarly, tropical regions in many Latin American and Asian countries enable the growth of high value fruits (like grapes, bananas, etc.).

Currently, most non-traditional crops in Africa are produced for export to the European markets, while in Latin America most non-traditional crops are exported to North America. Products from Asia go either to European or North American markets, depending on transportation costs, market competition, and whether the product adheres to the food safety requirements of the destination markets. Both national and international firms that source supplies from these countries have high standards and provide technical assistance to their suppliers to ensure the delivery of products with certain safety attributes to high-end markets.

Food safety has received heightened attention in developed and developing countries. This has followed from an increased demand for safe food by households with rapidly rising incomes, technological improvements in measuring contaminants, the expansion in the set of food

\footnotetext{
${ }^{1}$ International Food Policy Research Institute, Markets, Trade, and Institutions Division, Research Fellow, c.narrod@cgiar.org and d.roy@cgiar.org.

${ }^{2}$ University of Nairobi

${ }^{3}$ la Facultad de Economía Universidad Autónoma de Baja California, Profesor-Investigador de la Facultad de Economía Universidad Autónoma de Baja California

${ }^{4}$ International Livestock Research Institute, Scientist (Agricultural Economist)International Livestock Research Institute

${ }^{5}$ Jawaharlal Nehru University graduate student
} 
exporting countries, and increased media and consumer attention on the risks of food borne illnesses associated with recent food scares (e.g., salmonella in cantaloupe, pesticide residues in green beans and grapes). In response, food retailers and food service firms in developed countries (DCs) have created private protocols relating to pesticide residues, field and packinghouse operations, and traceability. Likewise, governments in both DC and LDCs have responded with voluntary and occasionally mandatory programs for food safety. Among the examples of such initiatives are the programs to register pesticides in Morocco (World Bank 2005) and the implementation of Hazard Analysis Critical Control Points (HAACP) programs in China to reduce sanitary and phytosanitary problems in canned food, aquatic products, meat and meat products, frozen vegetables, fruit/vegetable juice, and frozen convenience food containing meat or aquatic products (Dong and Jensen 2004).

While the development of food safety standards has reduced the risks from foods, it has often come at the cost of temporary import bans, particularly of LDC food exports to DC markets. During May 1999-April 2000, the number of detentions by the US originating from 52 countries was 9,875, with India accounting for the most detentions. During December 2001-November 2002, 997 detentions from India resulted in 2.6 million dollars worth of rejections of Indian exports (Mehta and George 2003). Recently, between February 2006 and January 2007, the number of detentions was 16,818 (FDA 2007). India again faced the highest number of detentions with a total of 2,085 detentions.

The increased food safety standards in both developed and developing countries can potentially exclude small farmers who face four distinct problems: 1) how to produce safe food; 2) how to be recognized as producing safe food; 3) how to identify cost-effective technologies for reducing risk; and 4) how to be competitive with larger producers (Narrod et al.. 2005). As supply chains become more complex, supply chain management (SCM) plays an increasingly important role in the delivery of high-value agriculture (HVA) products to distant markets. Given the perishable nature of HVA and the demand for quality and safety attributes, relationships, networks, skills, and coordination mechanisms are needed to manage the flow of products between intermediaries and ensure that the quality specifications are met. A variety of institutional arrangements such as collective action (CA) and forms of public-private partnerships (PPPs) can play a key role in creating such links. Further, producer groups organizing through 
cooperatives and monitoring their own food safety requirements through CA often become attractive to buyers who are looking for ways to ensure traceability.

This paper compares how small producers of fruits and vegetables (F \& V) in different countries have responded to increased demand for food safety from the markets they export to. The three cases are green beans in Kenya, cantaloupe in Mexico, and grapes in India. These cases differ in the ways in which they have adapted to the changes in international food safety standards (IFSS) and the types of institutions that have emerged to ensure compliance with IFSS.

The green bean exports from Africa that go to the European supermarkets are mostly in a pre-packed, pre-cut form, which normally requires a large investment to coordinate supply and upgrade hygienic conditions at the farm/packing house. It moreover requires a mechanism such as third party certification to ensure that specific standards are met. Findings from Okello (2005) suggest that CA was helpful for small farmers in overcoming entry barriers created by IFSS.

A similar success story in horticultural exports from India is that of a marketing partner named Mahagrapes to a collection of cooperatives that started exporting grapes to Europe in the early 1990s. As reported by Roy and Thorat (2006), in the first five years of exports, the cooperatives faced extremely high rates of rejection (at times greater than 80 percent). With the aid of the public sector, the cooperatives were able to install cold chains and pre-cooling facilities, and facilitate high rates of information dissemination related to IFSS. Consequently, the rejection rates came down substantially to less than 10 percent in late 90 s and to less than 1 percent after 2001.

The third case based on Avendaño et al. (forthcoming) relates to the cantaloupes from Mexico exported to the US that were implicated in food safety concerns in 2000, 2001, and 2002. This resulted in a ban on imports from all Mexican sources in 2002. Later, the US opened the market to selected firms with Mexican and US government approval. When the US firms began demanding Good Agricultural Practices (GAPs) and Good Manufacturing Practices (GMPs), to minimize microbial contamination in fresh produce, the end result was a two-tier system where larger farmers catered to export markets and the smallholders to domestic markets. Importantly, given that very little time has elapsed since the food safety shock, there has been an absence of both CA and PPPs in this case.

The paper is organized as follows. Section 2 briefly discusses the growth in supply of fruits and vegetables throughout the world over the last several decades and how less developed 
countries have responded. Section 3 looks at the development of various domestic and international food safety standards (such as HACCP, traceability, supermarket code of practices) for these suppliers. Section 4 looks at the role of supply chains in the delivery of fruits and vegetables, and the market outcomes that are likely to prevent smallholders from accessing these supply chains. It also briefly discusses the role played by different institutions in enabling smallholders to access the HVA chains. Section 5 focuses on the three cases involving smallholders. Section 6 looks at the specific difficulties smallholders face in these chains. Section 7 discusses the institutional mechanisms that have facilitated smallholders in overcoming constraints relating to the IFSS in these specific cases. Section 8 presents the conclusions.

\section{GROWTH OF THE SUPPLY OF FRUITS AND VEGETABLES AND THE RESPONSE OF LDCS}

Since 1971, global agricultural exports have grown at 3.0 percent per year in real terms compared to production growth at 0.7 percent per year thus doubling the share of production to exports (from 19 percent in 1971 to 40 percent in 2003).6 The composition of exports has also changed for both developed and developing countries (Minot and Roy 2006) with a shift towards HVA products like fruits and vegetables, fish, and livestock, even though these are highly perishable and subject to stricter SPS requirements (Figures 1 and 2). In 1982, beverage crops and spices (particularly coffee, tea, and cocoa) were the largest agricultural exports. Since then, net exports of $\mathrm{F} \& \mathrm{~V}$ and fish and seafood have increased almost four-fold (for F\&V from US\$5.3 billion in 1982 to US\$20.1 billion in 2003). During this same period, fish and seafood exports reached US $\$ 17.5$ billion in 2003, becoming the second-largest component in exports. Currently, fresh food exports account for half of all food and agriculture exports from LDCs to high income countries; however, these products may be subject to greater food safety risks and trade barriers arising from SPS regulations (Unnevehr 2000).

\footnotetext{
${ }^{6}$ These calculations are based on FAO statistics for agricultural exports and the World Development Indicators for agricultural value added and the US dollar GDP deflators.
} 
Figure 1: Composition of global agricultural exports ( \% of value)

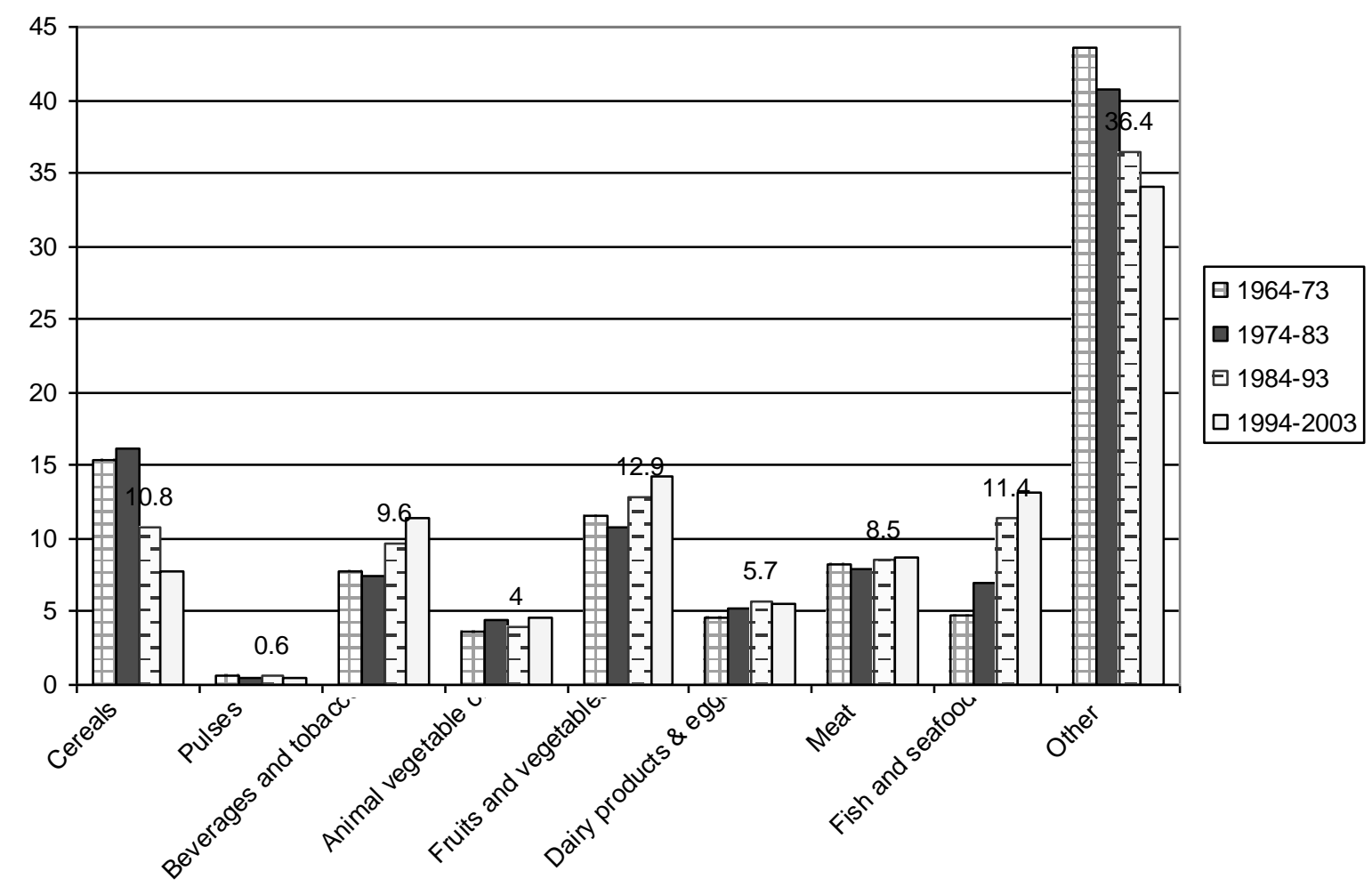

Source: FAOStat

Note: Crop and livestock exports from FAO statistics on primary agricultural products. Fish and seafood exports include both processed and unprocessed 
Figure 2. Net agricultural exports of developing countries

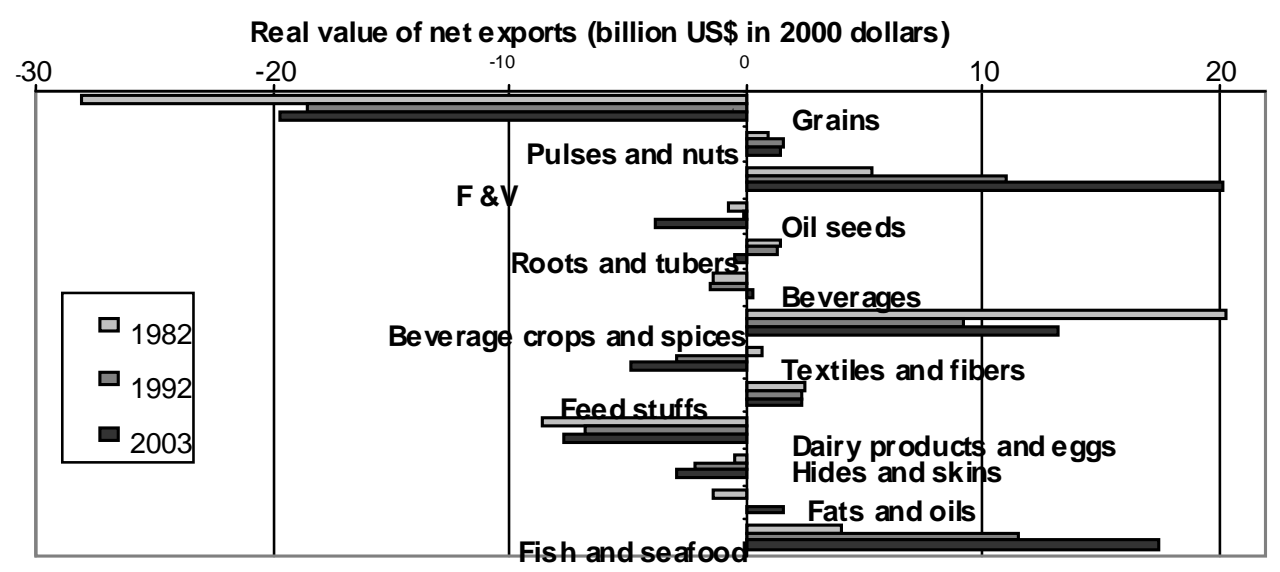

Source: FAOStat (2005) for trade in crops and FAO (2004) for fishery trade.

\section{DEVELOPMENT OF FOOD SAFETY STANDARDS AND REGULATIONS}

Modernization of marketing channels is characterized by a stricter set of food safety and quality standards. Henson and Hooker (2001) and Henson and Reardon (2005) point that it is private and not public standards that are becoming the predominant drivers of the agri-food systems. Loader and Hobbs (1999) suggest that in developing countries, low institutional capacity often limits the enforcement of even mandatory public standards leading firms to increasingly rely on private standards. Greater use of private standards is aimed at responding to consumers' quality preferences and reducing the costs of improved quality of inputs (Reardon and Berdeque 2002).

WTO members adhere to both the SPS and the agreement on Technical Barriers to Trade (TBT). These agreements provide broad guidelines for choice of product standards but accept national sovereignty in adopting standards provided they could be justified based on risk perceptions and scientific assessment. Some nations have moved to harmonize food safety regulations, such as the attempt to harmonize pesticide residue limits under the auspices of Liaison Committee for Caribbean, Africa, and Pacific (COLECAP). Concurrently, there has been a rise in the number of private standards such as Euro Retail Produce Group's Good Agricultural 
Practices (EUREPGAP), ChileGAP, KenyaGAP, ChinaGAP, Naturane [Spain], New Zealand Fresh Produce Approved Supplier Program, and Mexico Supreme Quality GAP. Besides, major supermarkets have their own standards like Tesco's Nature's Choice and Mark \& Spencer's Farm to Fork that require compliance via third party certification (Hatanaka et al. 2005).

The spurt in private standards has been partly driven by the events of food safety failures in the eighties and nineties (Dolan and Humphrey 2000; Dolan et al.. 1999; Freidberg 2003 and 2004). With several standards in practice, there have been attempts to harmonize globally with the formation of Global Food Safety Initiative (GFSI). The major goal of GFSI was to create a global set of voluntary but universally accepted standards of food safety, quality and security (Freidberg 2005). In case of pesticide residue limits for example, the GFSI intended to eliminate situations where some countries demand compliance with Codex Alimentarius, while other impose their own limits.

As it is difficult for the supermarkets to identify products grown under specific protocols, firms meeting guidelines try to distinguish themselves. Thus, in developed countries, retailers have developed private food safety protocols. Reardon et al.. (2003) suggest the rise of private standards as 1) strategic tools by the supermarkets to differentiate themselves; 2) instruments of supply chain coordination by standardizing product requirements across suppliers; 3) substitutes for missing or inadequate standards in less developed regions; and 4) strategic tools over the informal sector by claiming better food safety. 


\section{ROLE OF SUPPLY CHAINS IN THE DELIVERY OF FRUITS AND VEGETABLES}

\section{Types of markets available to producers in LDCs}

Currently, in most developing countries producers supply to three different markets: the domestic traditional markets, modern urban markets, and export markets. These markets differ in several organizational respects but, most importantly, in their demand for food safety (World Bank 2006 - Table 1). The food safety requirements are most stringent in the export markets (in high income countries) followed by the modern domestic urban markets. 
Table 1. Three types of markets and their characteristics

\begin{tabular}{|c|c|c|c|}
\hline & & Types of market & \\
\hline $\begin{array}{l}\text { Market } \\
\text { characteristics }\end{array}$ & $\begin{array}{l}\text { Traditional local fruit } \\
\text { and vegetable markets }\end{array}$ & $\begin{array}{l}\text { Emerging modern urban } \\
\text { domestic markets } \\
\text { (supermarkets, tourist } \\
\text { hotels/restaurants, } \\
\text { educated affluent } \\
\text { consumers) }\end{array}$ & $\begin{array}{l}\text { Export markets in industrial } \\
\text { countries (retail markets, } \\
\text { modern food services }\end{array}$ \\
\hline $\begin{array}{l}\text { Food safety } \\
\text { control. }\end{array}$ & $\begin{array}{l}\text { Little consumer } \\
\text { awareness, concern. } \\
\text { Little private effort. } \\
\text { Government control. }\end{array}$ & $\begin{array}{l}\text { Emerging consumer } \\
\text { awareness, concern. } \\
\text { Retailers try to control and } \\
\text { sell "safety". }\end{array}$ & $\begin{array}{l}\text { High consumer concern. } \\
\text { High retailer requirements } \\
\text { imposed on suppliers. }\end{array}$ \\
\hline $\begin{array}{l}\text { Standardization, } \\
\text { grading, supply } \\
\text { Supply-chain } \\
\text { organization }\end{array}$ & $\begin{array}{l}\text { Virtually absent. } \\
\text { Irregular supply. } \\
\text { Supply-driven. } \\
\text { Transaction-based. } \\
\text { Little or no net benefit } \\
\text { from coordination. } \\
\text { Little durability in } \\
\text { relation between private } \\
\text { actors. } \\
\text { No technical } \\
\text { cooperation. }\end{array}$ & $\begin{array}{l}\text { Emerging importance of } \\
\text { grading, stable supply. } \\
\text { Efforts by retailers to } \\
\text { control quality, safety, and } \\
\text { reliability of supply. } \\
\text { Net financial benefits from } \\
\text { coordination still fragile. } \\
\text { Emerging coordination, } \\
\text { occasional technical } \\
\text { support. }\end{array}$ & $\begin{array}{l}\text { High requirements of grading, } \\
\text { consistency, supply schedule. } \\
\text { Strongly demand-driven. } \\
\text { Durable relations within supply } \\
\text { chain, often on contractual basis. } \\
\text { Cooperation between buyers, } \\
\text { exporters, growers on } \\
\text { technology, information, } \\
\text { sometimes on finance. }\end{array}$ \\
\hline $\begin{array}{l}\text { Price level for } \\
\text { grower and } \\
\text { consumer }\end{array}$ & $\begin{array}{l}\text { Relatively low. } \\
\text { Limited willingness to } \\
\text { pay for quality and } \\
\text { safety. }\end{array}$ & $\begin{array}{l}\text { Moderate. } \\
\text { Moderate willingness to pay } \\
\text { for quality and safety. }\end{array}$ & $\begin{array}{l}\text { Relatively high. } \\
\text { High willingness to pay for } \\
\text { quality and safety. }\end{array}$ \\
\hline Value added & Very low & Low/moderate & Moderate/high \\
\hline $\begin{array}{l}\text { Trust between } \\
\text { buyers and sellers }\end{array}$ & Not very important. & Of emerging importance. & $\begin{array}{l}\text { Crucial factor for long-term } \\
\text { successful relations. }\end{array}$ \\
\hline $\begin{array}{l}\text { Competitiveness } \\
\text { depends mainly on. }\end{array}$ & Supply at low cost. & $\begin{array}{l}\text { Sufficient quantity of } \\
\text { improved quality. }\end{array}$ & $\begin{array}{l}\text { Large quantity required. } \\
\text { Efficient, effective coordinated } \\
\text { supply chains. } \\
\text { Flexible response to changing } \\
\text { demand. } \\
\text { Market and product innovation. }\end{array}$ \\
\hline $\begin{array}{l}\text { Participation of } \\
\text { small-scale } \\
\text { producers. }\end{array}$ & No constraints. & $\begin{array}{l}\text { Emerging constraints in } \\
\text { meeting requirements of } \\
\text { quality, safety, consistency } \\
\text { of product, regular supply. }\end{array}$ & $\begin{array}{l}\text { Only if well organized in out- } \\
\text { grower schemes and able to } \\
\text { guarantee safety and uniform } \\
\text { quality. }\end{array}$ \\
\hline
\end{tabular}




\section{CONSTRAINTS FACING THE SMALLHOLDERS IN THE EMERGING FOOD SYSTEM}

The new and emerging food system (dominated by domestic urban market and export markets) with high demands for compliance with food safety and traceability disfavor the smallholders due to high coordination costs. The problem is exacerbated by geographic dispersion, low education, and poor access to capital and information (Poulton 2005; Humphrey 2005; Rich and Narrod 2005). Because of high transaction and marketing costs of sourcing from smallholders, major exporters produce HVA on their own farms or source from medium and large outgrowers trained and trusted to deliver on both traceability and food safety requirements.

The smallholders face problem in the two dynamic markets in meeting the standards as well as in ensuring the delivery of a regular supply to their buyers. The list of constraints that smallholders face in the HVA markets given below draws from Rich and Narrod (2005):

- High fixed costs in production and marketing, especially due to the need to comply with the standards given high perishability.

- Difficulties in guaranteeing safe products. This can arise either in terms of the quality or the misuse of inputs or the lack of knowledge about the introduction, growth, and transport of pathogens, which can be magnified as products move along the supply chain. For credence goods, reputation matters significantly for demand creation. Smallholders usually have a small history of presence in the markets and lack branding.

- Asymmetric and incomplete information and high transaction costs may exist between actors in the supply chain. Lack of information regarding production and marketing can especially deter smallholders as procurement and processing of information involves large fixed costs.

- Lack of incentives and resources to invest in quality improvement, low access to credit, and the low returns from investing in quality (as they lack reputation) disadvantage the small farmers.

The supply chain in most developing countries is often characterized by transactions in spot markets, implying limited coordination among farmers, traders, and consumers. This lack of coordination coupled with poor infrastructure (for example, absence of cold storage) imply that participants lack incentive to reduce microbial pathogens, mycotoxins, and pesticide residues since the penalties for low quality are not enforceable (Narrod et al. 2005). 
The economies of scale become prominent in the presence of FSS, thus disadvantaging the smallholders. Consider, for example, the procurement of information regarding FSS. This information, once obtained, can be disseminated at low marginal costs. Unless there is a large volume of output over which the fixed costs can be distributed, it will not be economical to incur these transaction costs defined broadly to include costs for the collection of market information, negotiations, monitoring, and enforcement of business transactions (Jaffee and Morton 1995). Additionally, marketing costs (such as requirement of cooling) require lumpy investments leading to scale economies. In HVA chains, smallholders are thus likely to face problems in quality control, handling, and storage (Bienabe and Sautier 2005). Moreover, once involved in HVA chains, smallholders individually enjoy only limited bargaining power (Kaplinsky and Morris 2001).7

\section{Role of Institutions in enabling smallholders market access in HVA chains}

Given the constraints outlined above, the focus of this study is on CA and PPPs in enabling smallholders to access the HVA chains with FSS. Conceptually, the role of CA arises wherever there are economies of scale in production or in marketing. This includes the role of farmer groups in being better able to ensure traceability. In these chains, the costs for the establishment of traceability are lower for firms and farms with collective action than without it. Similarly, collective action has a rationale if agents in the supply chain have different comparative advantages. Thus, a producer group (with comparative advantage in production) could benefit from collaboration with agents that have expertise in marketing.

Table 2 below presents a summary of the different processes and the role that CA plays in each context. This list is not intended to be exhaustive but is aimed at presenting indicative cases pointing to a basis for CA. In exporting, information about the demands of the markets and the terms and conditions of the contract and the process of the establishment of contracts has to

\footnotetext{
${ }^{7}$ Some of these constraints remain unresolved owing to government over-regulation, taxes, or tariffs that raise the cost of supply chain development and lower the benefits of participation. Limits or bans on foreign investment reduce the benefits from technical expertise and coordination that foreign participants can bring. Even when regulatory norms are appropriate, changes in consumer demand can have negative impacts on smallholders if retailer's sourcing decisions change in response (Humphrey 2005).
} 
precede the production process. Procurement and processing of information clearly involves fixed costs. Similarly, negotiation of contracts might involve a big component of costs not related to output. Hence, these create a clear basis for grouping of small farmers to overcome diseconomies of scale.

Table 2. Production processes in markets with IFSS and the role of collective action

\begin{tabular}{lll}
\hline $\begin{array}{l}\text { Supply Chain } \\
\text { Process }\end{array}$ & Role played by collective action \\
\hline $\begin{array}{l}\text { Pre- } \\
\text { production }\end{array}$ & - & $\begin{array}{l}\text { Procurement of information about markets and the process of formation of } \\
\text { contracts }\end{array}$ \\
& - & Dissemination of the information relating to IFSS \\
Production & Undertaking of lumpy investments \\
& - Procurement of cheaper inputs through bulk buying \\
Post harvest & Establishment of traceability system \\
and Marketing & - Collective marketing leading to reduced costs (for example in transport) \\
& - Collaboration with marketing experts
\end{tabular}

Additionally, PPPs might be required to play a complementary role in linking small farmers with HVA markets. The traditional public supply functions can be inadequate to meet the needs of the HVA supply chains from the perspective of the smallholders. Traditional public sector activities such as extension, research and development, and price and marketing policies have been largely commodity-based and hence may not provide the support smallholders require in a HVA supply chain. The private sector has traditionally been directly involved in the production, marketing, and distribution of agricultural commodities, the rise in HVA commodities giving an ever-larger and more specific role to the private actors.

Table 3 presents the different supply chain support processes and the institutional roles played by the private and the public sectors. Wherever the public or the private sector by itself cannot provide the supply chain support that caters to the needs of the smallholders, there arises a need for partnerships. The last column in table 3 provides insights on the basis for PPPs in HVA chains. For example, in the extension services relating to HVA, the public knowledge might be limited while the access to private information might also be constrained owing to low purchasing power of the smallholders. 
Table 3. Public and private sector roles in the supply chain management of HVA

\begin{tabular}{|c|c|c|c|c|}
\hline \multirow{2}{*}{$\begin{array}{l}\text { Supply Chain Support } \\
\text { Processes }\end{array}$} & \multirow{2}{*}{$\begin{array}{l}\text { Needed Roles for } \\
\text { SCM }\end{array}$} & \multicolumn{2}{|c|}{ Traditional Institutional Roles } & \multirow{2}{*}{$\begin{array}{l}\text { Market or } \\
\text { government failures } \\
\text { affecting } \\
\text { smallholders }\end{array}$} \\
\hline & & Public Sector & Private Sector & \\
\hline Extension services & $\begin{array}{l}\text { Knowledge of } \\
\text { specialized } \\
\text { techniques for HVA }\end{array}$ & $\begin{array}{l}\text { Technical } \\
\text { assistance in } \\
\text { farming practices }\end{array}$ & $\begin{array}{l}\text { Services to farmers } \\
\text { and firms linked to } \\
\text { private company }\end{array}$ & $\begin{array}{l}\text { Low and variable } \\
\text { access to public or } \\
\text { private extension; } \\
\text { limited public } \\
\text { knowledge of new } \\
\text { techniques }\end{array}$ \\
\hline $\begin{array}{l}\text { Infrastructure } \\
\text { development }\end{array}$ & $\begin{array}{l}\text { Management of flows } \\
\text { between chain links } \\
\text { quickly and } \\
\text { efficiently; Reduce } \\
\text { distribution costs to } \\
\text { remain competitive }\end{array}$ & $\begin{array}{l}\text { Public } \\
\text { infrastructure } \\
\text { (roads, ports, } \\
\text { storage facilities); } \\
\text { public distribution }\end{array}$ & $\begin{array}{l}\text { Private infrastructure } \\
\text { (processing, storage); } \\
\text { logistics }\end{array}$ & $\begin{array}{l}\text { Uneven development } \\
\text { biased against } \\
\text { smallholders, private } \\
\text { development difficult } \\
\text { for smallholders or not } \\
\text { attuned to small } \\
\text { farmer's needs }\end{array}$ \\
\hline Information services & $\begin{array}{l}\text { Integration of } \\
\text { information flows } \\
\text { across supply chain }\end{array}$ & $\begin{array}{l}\text { Provision of } \\
\text { public statistics on } \\
\text { prices, production, } \\
\text { etc.; information } \\
\text { on varieties } \\
\text { through extension }\end{array}$ & $\begin{array}{l}\text { Private marketing } \\
\text { information services } \\
\text { (MIS) and electronic } \\
\text { data interchange } \\
\text { (EDI) }\end{array}$ & $\begin{array}{l}\text { Reliance on public } \\
\text { information systems } \\
\text { not tuned to market } \\
\text { needs, exclusion from } \\
\text { private sources for } \\
\text { inability to pay }\end{array}$ \\
\hline $\begin{array}{l}\text { Certification, grades, } \\
\text { and standards }\end{array}$ & $\begin{array}{l}\text { Consistent, credible } \\
\text { application of } \\
\text { standards on food } \\
\text { safety and quality } \\
\text { specifications }\end{array}$ & $\begin{array}{l}\text { Public } \\
\text { certification and } \\
\text { development and } \\
\text { enforcement of } \\
\text { public standards } \\
\text { and regulations }\end{array}$ & $\begin{array}{l}\text { Private certification } \\
\text { and development and } \\
\text { enforcement of } \\
\text { private standards; }\end{array}$ & $\begin{array}{l}\text { Smallholders' ability } \\
\text { to meet public or } \\
\text { private standards } \\
\text { limited; Development } \\
\text { not based on } \\
\text { smallholder needs }\end{array}$ \\
\hline $\begin{array}{l}\text { Coordination } \\
\text { mechanisms }\end{array}$ & $\begin{array}{l}\text { Ensuring consistent } \\
\text { delivery of high- } \\
\text { quality products }\end{array}$ & $\begin{array}{l}\text { Creation and } \\
\text { enforcement of } \\
\text { regulations to } \\
\text { ensure } \\
\text { competition; } \\
\text { mandatory } \\
\text { cooperatives } \\
\text { (centrally-planned } \\
\text { economies) }\end{array}$ & $\begin{array}{l}\text { Development of } \\
\text { contracts and } \\
\text { marketing agreements } \\
\text { with suppliers }\end{array}$ & $\begin{array}{l}\text { Limited enforcement } \\
\text { of contracts biased } \\
\text { against small farmers; } \\
\text { divergence in market } \\
\text { power between chain } \\
\text { actors }\end{array}$ \\
\hline
\end{tabular}


CA and PPPs clearly play complementary roles in linking small farmers with HVA markets. Where CA is necessary under many circumstances, it may not be sufficient. Consider a group of small farmers that has to finance a lumpy investment. To this group, the private sector loans might not be forthcoming at terms that the group finds economical. The private discount rates tend to be high, while gestation lags in investments, especially with smallholders, tend to be long. This creates a role for the public sector with lower discount rates (possibly with some subsidy) in credit markets.

\section{FRUIT AND VEGETABLE PRODUCTION AND THEIR SUPPLY CHAINS FROM THREE CASE STUDIES}

Following on the discussions above, we focus on 3 supply chains involving smallholders for fruit and vegetable exports in India, Kenya, and Mexico. In Kenya, the domestic market for green beans hardly exists. The smallholders have been involved in producing beans for export for some time even before the relatively recent demand for food safety. In the Mexican case, smallholders were supplying both the domestic and the export markets with cantaloupes until the outbreak of salmonella, which resulted in a total ban on all exports for a year. Exports only resumed a year later when firms adopted voluntary best management practices. In the process they began to source primarily from medium and large scale producers. In the Indian grape case, Mahagrapes, the marketing partner of cooperatives, built upon an existing network of producer organizations that were already producing good quality grapes (including organic farming) but lacked the marketing expertise for export. Now, the smallholders are actively involved in exports and successfully meet the FSS of the western markets. Below we discuss these cases.

\section{Green Bean Production in Kenya8}

\footnotetext{
${ }^{8}$ From Okello et al. (forthcoming)
} 


\section{Kenyan green bean supply chains}

Currently, green beans are marketed through three chains - the export supermarket chain, the export wholesale chain, and the domestic chain (figure 3). These chains are distinguished by the degree of coordination following the need to comply with IFSS and the demand for a traceability system. The supermarket chain is the most closely coordinated and typically requires establishment of a functional traceability system. In Figure 3, traceability requirements are represented by a broken line. 
Figure 3. Kenya's green beans supply chain

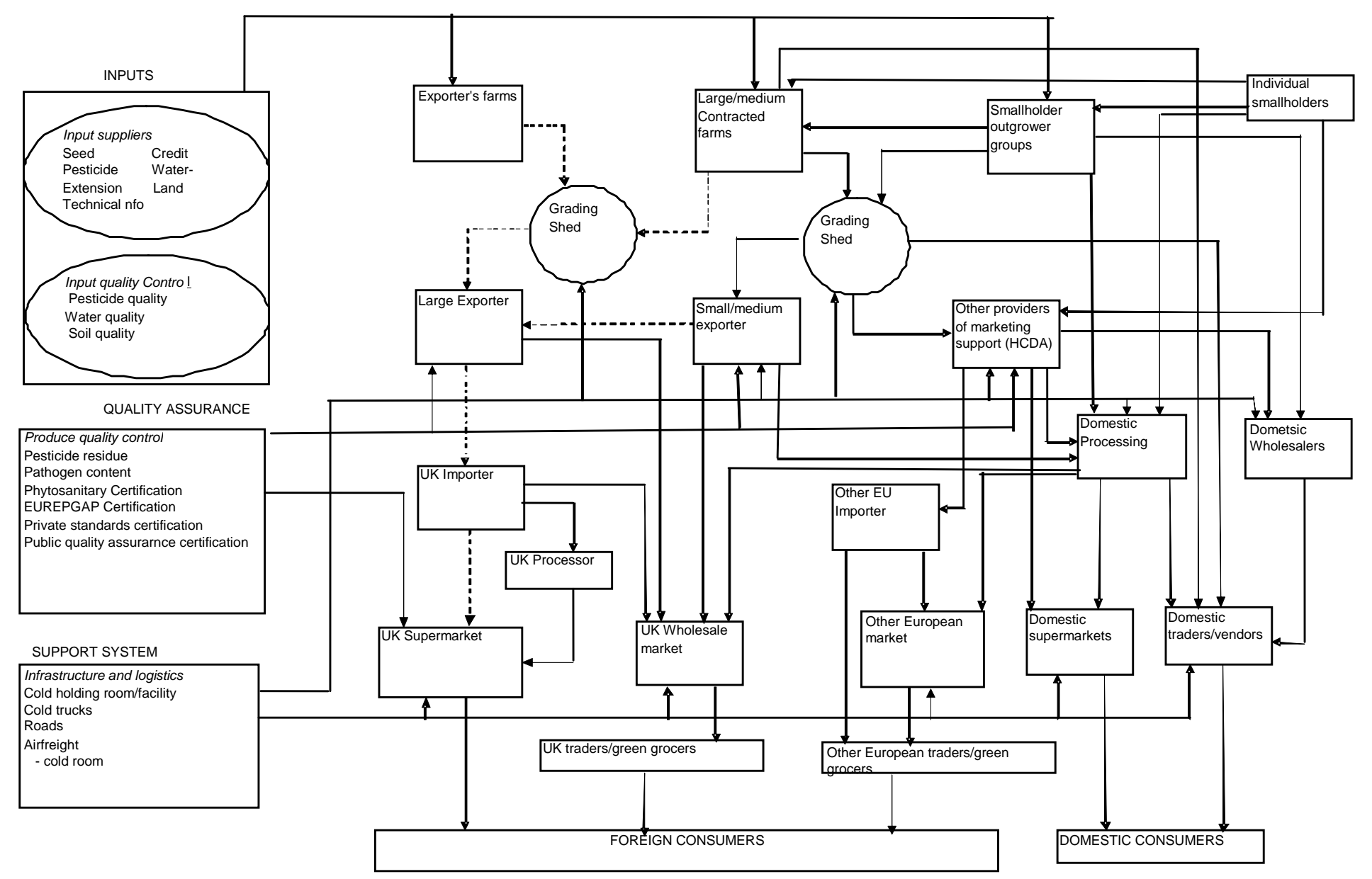

Source: Okello et al. (forthcoming) 


\section{Supermarket chain}

The UK supermarket chain has the most stringent food safety requirements (Singh 2002; Jaffee 2003; Henson, et al. 2005). Green beans marketed through this chain must be certified (by an accredited third party) as meeting EUREPGAP, BRC, and, in most cases, retailers' private food safety protocols. The beans must be accompanied by a phytosanitary certificate issued by a competent authority guaranteeing absence of prohibited pests. In addition, the beans must be traceable from the retailer's shelf back to the grower's plot.

Handling and hygiene practices during harvesting, grading, and packing of green beans are all closely monitored. Growers are required to have a toilet, pesticide storage unit, and a facility for hand washing at the farm or the grading shed. Exporters to the EU supermarkets test the water and soil twice a year for pathogens. The exporters also require farmers to keep records of the type and quality of inputs (pesticide, water, or soil) used. These records accompany green beans to the exporters' packhouses. Farmers keep records of production and handling practices either individually or collectively (in case of a farmer group). In order to enforce compliance with these practices, EU importers have increased their monitoring and coordination of input use. They generally monitor the exporters expecting them to monitor growers in turn. Increasingly, some EU importers have extended their monitoring to farm level through regular visits.

The most serious attention to the possibility of contamination occurs in the exporters' packhouses. Exporters in this chain have all invested in packhouses with good manufacturing practices (GMPs). Workers are required to wear special clothing and rubber boots in the pack houses and to wash their hands at regular intervals or when they change shifts. Some exporters monitor worker hygiene (especially the washing of hands) in the packhouse. Such exporters randomly swab the hands of workers and test for pathogens. If the swab tests positive for any of the pathogens of concern, that worker is penalized. All containers used at various stages of the processing are color-coded to avoid mixing and cross-contamination with pathogens. In addition to strict adherence to hygiene during processing (sorting, chopping, and arranging beans into trays), packing and bar coding are done under temperature-controlled conditions. 


\section{Wholesale chain}

Green beans from most small and medium farmers feed into the wholesale chain where monitoring and coordination is less pronounced. Here the focus is often on the physical characteristics (e.g., size, spotlessness) as opposed to the credence attributes (e.g., pesticide residue content). However, meeting the EU's public standards is mandated, and consistency of volume in supplies is desired. A large proportion of beans in this chain originate from the spot market (hence do not satisfy traceability) and are usually not grown under supervision by the exporter. Consequently, the quality (in terms of pesticide residues) cannot be ascertained even by inspection at the market. Generally, the wholesale chain is used by exporters who find it uneconomical to comply with the private FSS of the supermarkets. Such exporters are generally the small and medium sized lacking adequate quality management systems (Humphrey 2002).

\section{Domestic chain}

The FSS are least pronounced in the domestic chain comprising fresh or processed beans. The fresh green beans in domestic supermarkets tend to be the overflow from sales to UK supermarkets. Some fresh beans are sold also to the wholesale markets and to open retail. Currently, the supermarket buyers do not have any specific system of checking and verifying the quality. There is also no system of preventing contamination of beans with pathogens. Five firms in Kenya are involved in green bean canning and sell primarily to France. Since FSS is less stringent in canned beans, the processing firms source the majority of their green beans from smallholders. Indeed, the only FSS for processors is the pesticide residue limit. Thus, firms use their own pesticide applicators and handle the purchase and storage of pesticides themselves.

\section{Grape exports from India ${ }^{9}$}

In 2005, India was the third biggest producer of fruits and second largest vegetable producer in the world (FAO 2005). But India is a small horticultural exporter mainly because of lack of off-farm competitiveness (World Bank 2005). Smallholder dominated agriculture restricts the number of farmers able to adopt sophisticated farm practices and undertake the investments (like cold storage) to meet stringent IFSS (Umali-Deininger and Sur 2006).

\footnotetext{
${ }^{9}$ From Roy and Thorat 2006
} 


\section{India's grape supply chain}

Figure 4 shows the supply chain for the three main varieties of grapes produced by the grape farmers: viz. Thompson seedless, Sonaka, and Sharad seedless. The first variety is targeted mainly for exports to European markets. The Sharad seedless variety is sold mainly in the domestic market, while the Sonaka is marketed domestically and also exported to Gulf countries. 
Figure 4. Supply chain for Mahagrapes and independent grape producers

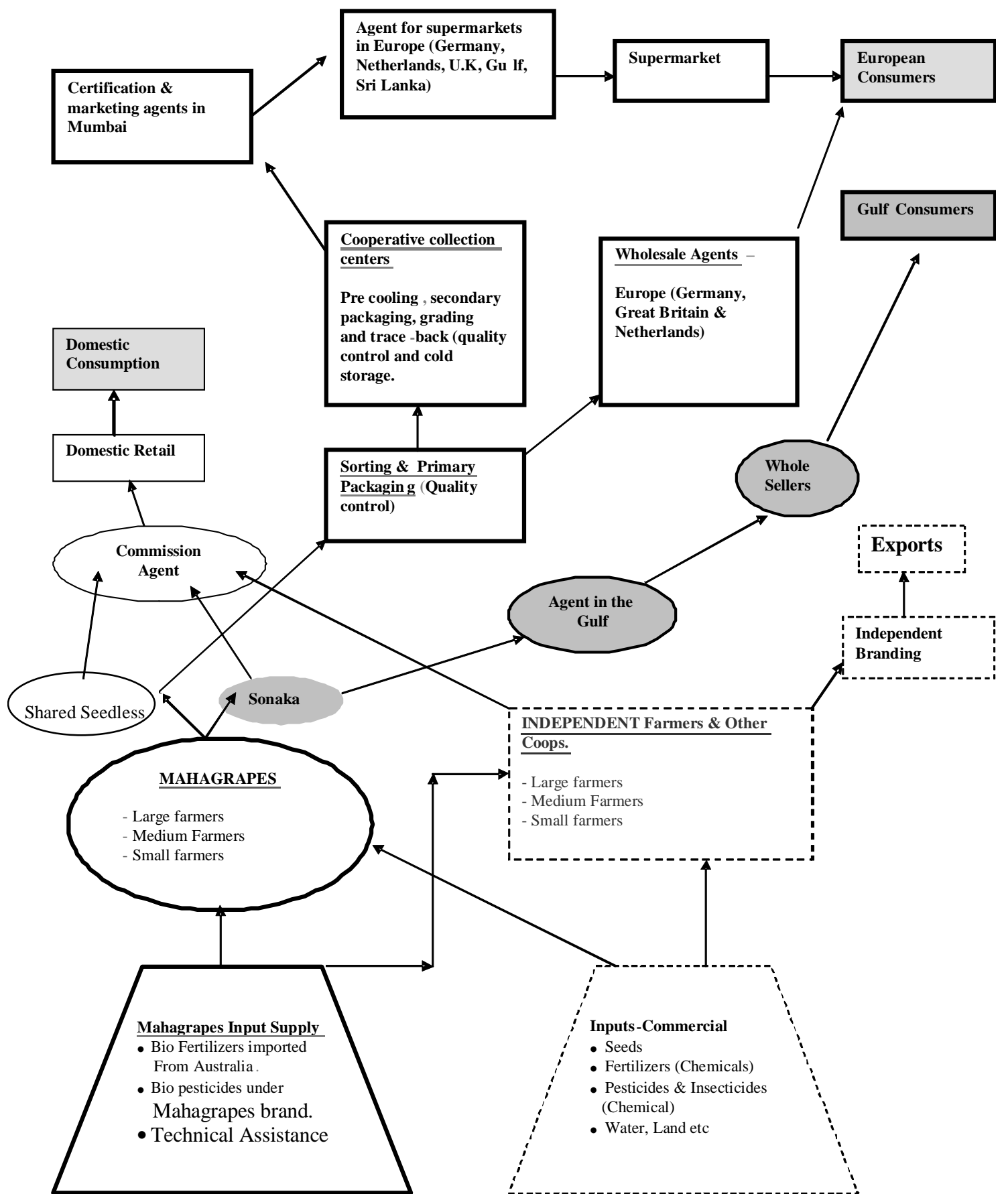




\section{Harvest and packing of grapes}

There are stringent requirements in pruning and packing of the grapes. After harvesting, the grapes are transported to a cooperative collection center where pre-cooling and cold storage facilities exist. Some amounts of grapes are screened off based on initial damage, bunch composition, etc. Some farmers, especially the small farmers, do the pruning near their farms and then transport grapes to the cooperative centers. Some grapes after the second round of tests may be rejected at the cooperative collection center. The grapes that are rejected at the collection center are generally sold to middlemen and find their way to the local market. The post harvest facilities have to meet the sanitation and hygiene requirements under the EUREPGAP. At the packing station before the grapes are packed, the packages are coded for traceability.

\section{Shipping}

Shipping for exports is done by the cooperative in collaboration with Mahagrapes. Refrigerated containers pick up grapes from the cooperative collection centers maintaining the cold chain. The cooperatives charge a logistic fee per unit of grape supplied. The grapes rejected for exports (similar to grapes intended for domestic markets) are shipped in non-corrugated boxes to local markets. They are not packed in pallets nor are they labeled for traceback. The export grapes are packed in pallets and covered with sulfur dioxide sheets (imported from China) to preserve quality as grapes are shipped by sea over long distance. If shipped for local markets, the mode of transport tends to be in open trucks with paper bags packed under wooden crates.

\section{Mexico's cantaloupe production10}

A salmonella outbreak in 2002 detected in shipments from Guerrero led to the ban of cantaloupe exports. Prior to the ban, almost 90 percent of Mexican F\&V exports were to the U.S. Following the ban, Mexican cantaloupe exports reduced by 97 percent, with a loss of 5,909 hectares under production (23.5 percent reduction) (Avendaño et al. forthcoming). Most U.S. retail firms after the outbreak started demanding suppliers to meet GAPs and GMPs to minimize microbial contamination in fresh produce. To meet this demand, the Mexican government tried to

\footnotetext{
${ }^{10}$ From Avendaño et al. (working paper forthcoming)
} 
develop a strategy by signing a memorandum of understanding on actions needed to comply. This was followed by the publication of an emergency regulation to develop a new FSS program for FVs.

With this in place, the U.S. opened the market to selected firms that gained Mexican and U.S. government approval, and a new program for imports of cantaloupe was announced in late 2005. To adopt GAPs, growers had to have technical assessments of their operations, make investments to bring their farms up to standards, and pay for third-party audits certifying compliance with GAPs.

\section{Mexico's cantaloupe supply chain}

Mexico's cantaloupe chain comprises two different streams (figure 5): one associated with export oriented large firms, and second involving smallholders catering to the international markets before the salmonella outbreak (mainly through big firms with packing facilities). 
Figure 5. Mexico's cantaloupe supply chain

MEXICAN CANTALOUPE: PROUUCTION AND MARKETING

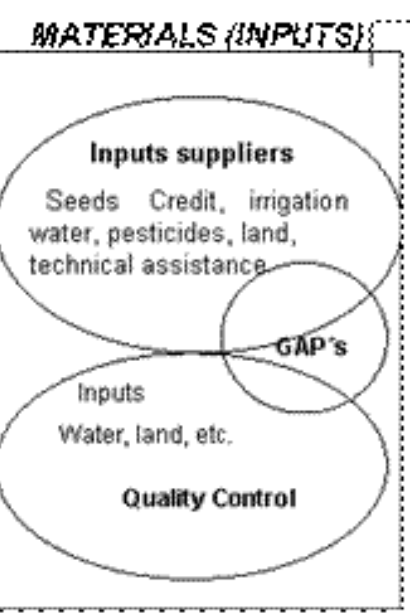

Owotits enpoplingis:

Product Quality

Pesticide residues (LMR)

Microbial (FSS)

Sanitary certification

Private Standards Certification

(TPC: OMP'S, EUREPGAP, others)

Public Certification (Senasica)

supor skpten

Logistic and introetructure
Cooler
Roads
Transpont
Traceback andrecal progams
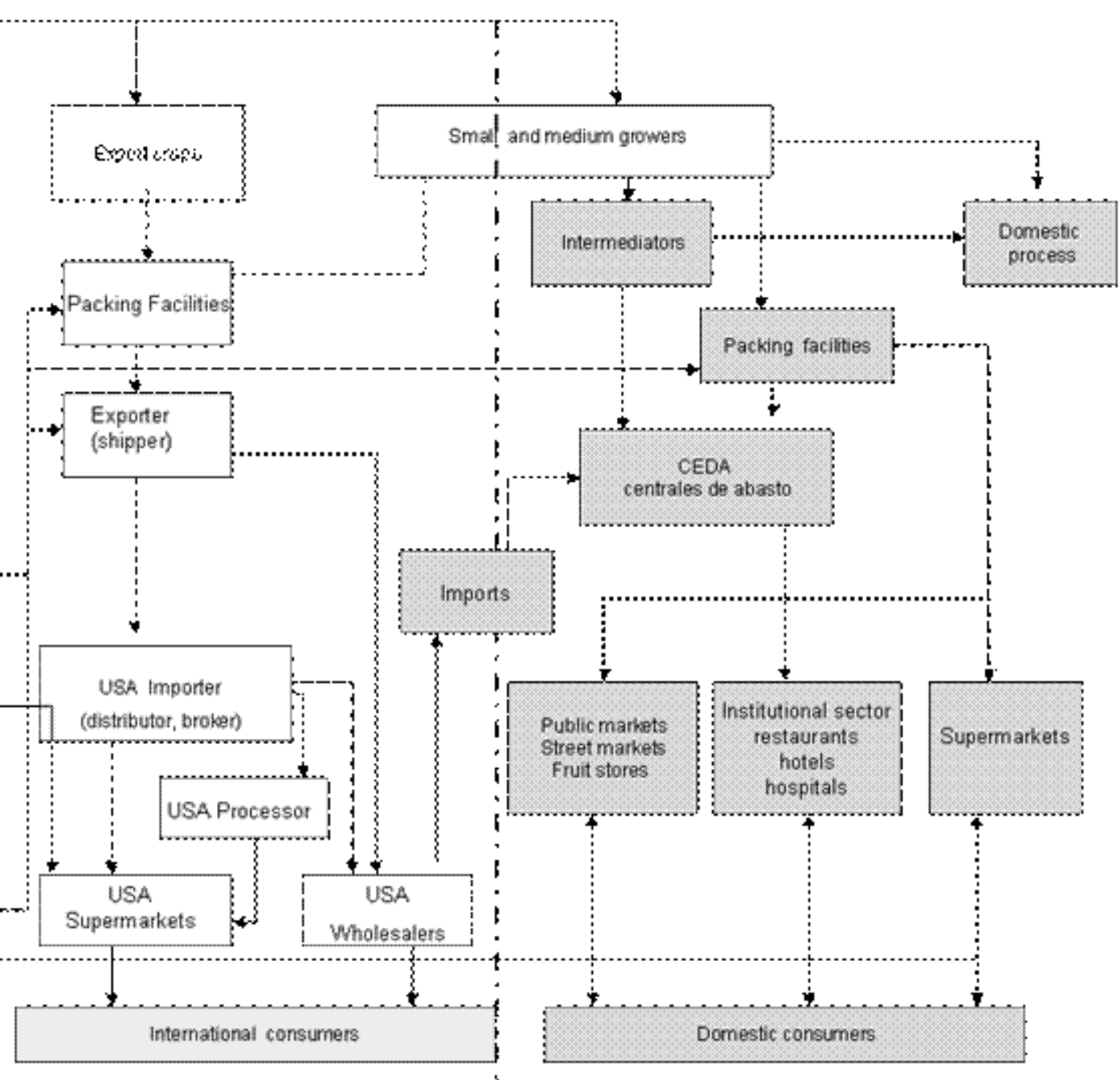

Source: Avendaño et al. (forthcoming) 


\section{Production}

In production, firms usually rent land to smallholders for production and in some cases contract with them. Nearly 825 hectares are used for this crop in Colima: 75 percent of the land use in cantaloupe belongs to an ejido system ( 1 to 14 hectares with 6 hectares as the average per grower), 25 percent to small property (up to 300 hectares); 29 percent of cantaloupe growers rent land for production, and 71 percent are smallholders that work on owned land.11

Most growers (92 percent) use drip irrigation, plastic quilted beds, and certified seeds. White fly is the main threat, but it is relatively under control with the techniques in use (drip and bed). Only 4 percent of growers qualify for GAPs. Moreover, there is no evidence of other types of microbiological risk reduction; thus, regaining of market access in the US seems unlikely in the short run. To implement a food safety program, growers have to start with incorporation of GAPs and pay attention to the quality of water, a major source of contamination.

\section{Harvest and packing}

Meeting GAPs during growing and harvesting can be difficult for small growers. They must keep records of fertilizers, irrigation, pesticides and chemicals applications, and observe the proper time to harvest (until chemicals are absorbed). Once harvested, big firms (export-oriented) send the product to the packing facilities for post harvest treatment, which includes washing, brushing, selection, pre-cooling, sizing, pre-packing, cold storage, and carton repacking. From packing houses the product goes to the market. Only two packing houses are in process to obtain a food safety certification to export to the USA. Small growers without a prior arrangement with a packing house have the choice to sell to a middleman at the orchard. Once in the packing house, if product does not meet the quality standards demanded by the packers, it can go to (fresh) domestic market or to the process industry without packing. If packed, product goes to fresh export market or domestic market.

\section{Shipping}

Shipping for export is usually done by the same growers (big firms that own transport and can preserve the cold chain). Export is done mainly through brokers and wholesalers in the

\footnotetext{
${ }^{11}$ The ejido is a tenure system through which the government promotes the use of communal land shared by the people of the community.
} 
North American market, and gets to the institutional sector (supermarkets, hospitals, restaurants, hotels, etc.) on the way to consumers. Product going to CEDA does not preserve the cold chain and is usually transported in open trucks. Once in CEDA, product is distributed to small buyers related to street markets, fruit stores, and public markets. Ninety percents of the produce goes to domestic markets and the rest to export.

\section{Marketing}

The producer may sell directly to a middleman. Sometimes cantaloupe is bought directly at the farm by a middleman, who can bring it to either the packing house, to the supply center, or to a domestic processor. For products going directly into the domestic processing, no post harvest processing is required. Domestic processors sell mostly in domestic markets in different forms: frozen or canned. The packing process is one of the most important phases in the cantaloupe chain. For export as well as for institutional markets, the facility must have a food safety program and be certified by a third party. For example, if product is going to the EU, it must comply with EUREPGAP; for the US, food safety certification is generally done by North American firms like Primus Lab recognized by the market.

The institutional sector gets its supply from CEDA or directly from packers. When products come from CEDA, it is difficult to trace back the origin. The supplies for the institutional sector in the US require a system of traceability. Direct access to supermarkets is recent for cantaloupe growers. Only 17 percent of Colima growers sell directly to supermarkets since they need to have packing facilities. Though an important market, the need for packing facilities and the delay in payments by supermarkets has obviated the participation of the small growers. In a study by ANTAD (2005), 38 percent of fresh fruit and vegetables go to public markets and 29 percent to supermarkets. The supply centers (CEDAs) are also the main importers for fresh products which they also import from the U.S. Sometimes, they are just returned exports. Most imports from the U.S. wholesalers go either to public markets, fruit stands, or to the institutional sector. 


\section{DIFFICULTIES SMALLHOLDERS HAVE IN PARTICIPATING IN THESE SUPPLY CHAINS}

With these stringent requirements in the coordinated supply chains with IFSS, we now focus on the difficulties that smallholders face in these specific chains.

\section{Smallholders in Kenyan green bean supply chain}

Prior to mid 1990s, Kenya's green bean industry was dominated by smallholders with their share in output being greater than 60 percent (Kimenye 1993). Currently, this share is believed to be less than 40 percent (Dolan et al. 1999; Dolan and Humphrey 2000; Jaffee 2003; Jensen, n.d.). High value products are labor intensive, making it cheaper to grow on family farms with self monitoring labor (Collins 1995). However, these advantages have generally been outweighed by the higher transaction costs of working with smallholders, and exporters have shifted from smallholders to medium and large scale, and own farms for green beans (Dolan and Humphrey 2000; Jaffee 2003).

The dominant transaction cost in linking with smallholders is the cost of monitoring compliance with IFSS and the insistence on traceability by importers. Medium and large outgrowers also have access to own, debt, or venture capital to invest in costly facilities required by IFSS including grading shed, cold storage, and pesticide storage unit (Jensen, n.d). The post harvest facilities involve lumpy investment and entail economies of scale; hence, competitiveness is achievable only with high volumes (Debertin 2002). The traceability and residue limit requirements further disadvantage the smallholders as they are poorly educated and/or unskilled. By comparison, larger farmers can invest in specialized skills needed to comply with FSS (Collins 1995).

\section{Smallholders in Indian grape supply chain}

Several market failures plague the supply chain of Indian horticultural exports. Most importantly, the Indian exports lack good reputation in external markets. Therefore, any private sector investment in quality improvement or branding is unlikely to be adequately compensated. 
Indeed, the large farmers export independently under their own brand. In addition, certification is expensive, and smallholders cannot individually bear the costs.

Several post harvest technologies (like cold storage) require lumpy investments, and credit constrained farmers would not be able to make those investments. In the limited cold storage facilities that exist, there is large monopoly power for the providers and, unless provided by the cooperative, small farmers cannot afford it. Also, the private sector has not invested in precooling facilities given the small paying capacity and gestation lags in such investment.

The presence of middlemen in these chains accounts for another market failure. The middlemen charge high commission costs ranging from 15 to 40 percent of the domestic consumer price for grapes (based on field survey of grape farmers). To the extent that smallholders rely more on middlemen, they are affected more adversely.

\section{Smallholders in the Mexican cantaloupe chain}

Several market failures arise also in Mexico's cantaloupe chain (figure 6). The first relates to imperfect information and access to inputs. Most smallholders rely on input suppliers for inputs on credit, but the cost of financing reflected in the final price is usually much higher than market rates. 
Figure 6. Mexico cantaloupe chain and market failures

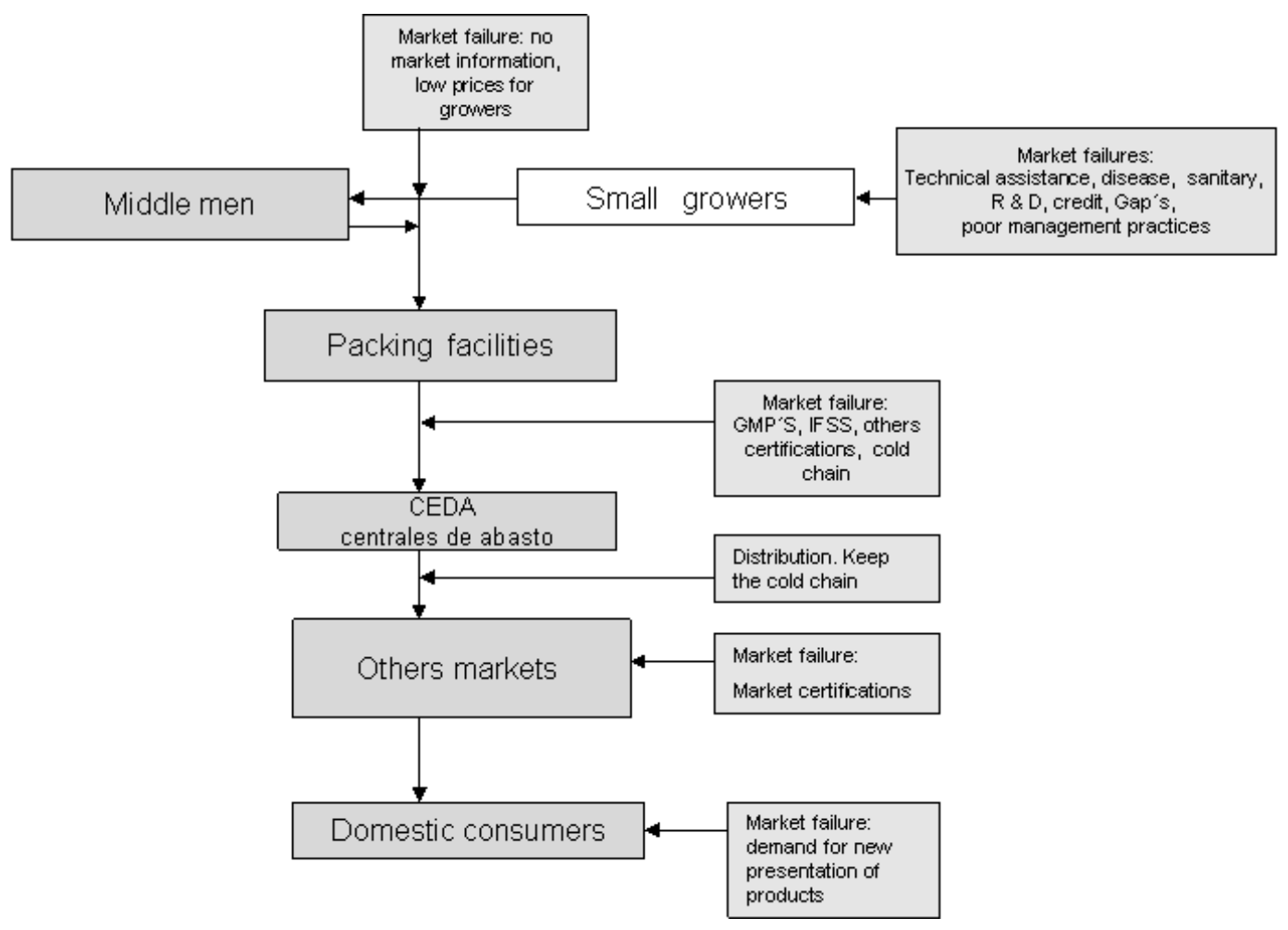

A second market failure is the lack of access to packing facilities for smallholders. Large packing firms pay small growers a price set by themselves, not by the market, and thereby limit the participation of small growers in this stage of the chain. A third market failure is due to the presence of the middlemen who tend to offer lower prices to small growers due to the lack of market information and the absence of a quality system that can lead to better prices. 


\section{ROLE OF VARIOUS INSTITUTIONS IN INVOLVING SMALLHOLDERS IN THESE MARKETS}

Thus, there are factors in these supply chains (some generic and some specific to the chains) that would exclude the smallholders without any intervention. As discussed above, owing to the nature of HVA export markets involving IFSS, there is rationale for CA and PPPs in marking these markets more accessible for smallholders.

Collective action for sustainable management of resources among resource dependent populations has been studied extensively (Bardhan and Dayton-Johnson 2002; Lam 1998; Kant 2000). The role of collective action in achieving market access through cooperatives has also been widely documented (Baron 1978, Ranade 1983, and Wilkins 1983, for example). The transaction cost approach to the determination of organizational and institutional structure explains organizational forms as originating to minimize the transaction costs in a given environment (Staatz 1984). The institutional structures and innovations that we discuss here aim to minimize the transaction costs and exploit the economies of scale wherever applicable.

\section{Coping strategies for smallholders in Kenyan green bean exports: The role of CA and PPP}

Two forms of institutional arrangements have enabled market access for the small farmers in fresh beans: contract production with individual farmers or with farmer groups (Okello et al., forthcoming). The contracted outgrowers in farmer groups are usually smallholders with weekly sales of fewer than 100 kilograms. Several of these farmer groups jointly invest in facilities needed to comply with IFSS and also have technical assistants or trained leaders that help members meet the standards. Buyers work very closely with groups in providing both training and other technical support to members and facilitate their compliance with the FSS.12

\footnotetext{
${ }^{12}$ One of the coping strategies adopted by small farmers as discussed above has been market switching. Several smallholders have shifted to producing for the canning industry. In 2000, only a few hundreds of farmers grew beans for the canning industry. Fintrac-Horticultural Development Center (a Kenyan NGO) estimates that by 2004, thousands of smallholder farmers were growing beans for one of Kenya's leading green bean canner, with 3000 having attained EUREPGAP certification. Less stringent FSS imply that the farmers are not required to invest in long term facilities (pesticide storage unit, shower room, toilet in the
} 
Apart from this endogenous adjustment by the small farmers, institutions have emerged to enable smallholders to access markets with IFSS. The arrangements comprise CA among farmers or with different agents in the supply chain and formation of partnerships among NGOs, donors, and the public sector. In Kenya, green bean farmer groups existed even prior to the IFSS. The reason they existed was primarily for marketing, i.e. to find a buyer and negotiate better prices for members. Beginning in the late 1990s (with IFSS), exporters began transforming the way these smallholder groups operated (Jaffee 2003).

First, the groups were reorganized and their sizes reduced from as high as 350 farmers to less than 30 farmers per group. The farmers were trained on IFSS and on the production practices. The farmers were then subjected to close monitoring under more formal contracts than the procurement arrangement that existed before. Some exporters supervised group members individually and penalized the individuals for violation of practices, but most supervised the group as a whole and penalized all the members for violations (Okello 2005). The farmer organizations also conduct training for members and facilitate farmer to farmer monitoring in the absence of the exporter's field technical assistant (TA) and/or to reinforce exporter's training. The organizations invite experts to train farmers on GAPs, especially on the observance of pre-harvest interval following application of pesticides, integrated pest management, packer hygiene, and establishing and maintaining a functional traceability system.13

Some exporters require the farmer organizations to hire their own technical assistants (TAs) who can respond to members' hygiene, pest, and disease problems readily, and a clerk. The TA occasionally conducts field visits with an exporter's agronomist as part of the training and also keeps records for all the members of the type, amount, and date of pesticides used. The clerk, on the other hand, enforces compliance with hygiene requirements within the grading shed. This strategy is used by a few leading exporters.

farm, grading shed) thus removing the scale-dependent determinants of competitiveness (FintracHorticultural Development Center 2004).

${ }^{13}$ The main benefit from grouping has been the lowering of per capita costs of compliance with the IFSS for the small farmers. Okello et al. (forthcoming) show that the costs of compliance with the IFSS for a small farmer would be around 10 times higher if they were not a member of a farmer group. Several costs of compliance involve fixed costs such as construction of grading sheds which, unless distributed over a large output, would make it uneconomical to access markets with IFSS. For example, on average for an individual small farmer, the costs of compliance with IFSS based on a conservative estimate would be almost 70 percent of the income, while in a 15 member group it would be just 4 percent. 
Some producer organizations instead hire a team of expert pesticide applicators that spray green bean fields for farmers under interlinked credit arrangements by the group. The TA dispenses only the right kind and quantity of pesticide based on the growth stage of the crop and outcome of pest scouting. Such producer organizations may also have their own pesticide stores. To ensure traceability, producer organizations jointly hire field technical assistants and depot/grading shed clerks who compile the records required under IFSS.

The organization of the producer groups and hence the CA among farmers as discussed above is tuned to enabling the small farmers to comply with IFSS. Hiring a technical expert or investing in facilities are possible because of joint sharing of costs. Most importantly, for the buyers, having the producer groups enables them to implement a functional traceability system whereby a clerk holds accounts from several small farmers at once and also creates a system of farmer to farmer monitoring, akin to group liability system in microfinance.

Where does the partnership with the public sector play a role here? First, the formation of producer organizations entails transaction costs related to search and screening of members. Therefore, formation of some smallholder organizations has been facilitated by the governments, exporters, non governmental organizations, and donors. Additionally, donor and NGO funding has sponsored farmer's EUREPGAP training, audits, and certification.

The government moreover has adopted some policies aimed at promoting compliance with IFSS such as i) partnering with donors and NGOs to provide training and physical infrastructure; ii) partnering with the fresh export industry to lobby importers for adaptation of EUREPGAP requirements to developing country conditions; and iii) conducting awareness campaigns and limited training to smallholder farmers on importance of meeting IFSS. The Government in partnership with Japanese International Cooperation Agency (JICA) established a company that owns cold storage facilities. This partnership has also trained more than 100 smallholder farmer group leaders as IFSS service providers and many farmers belonging to farmer groups on good agricultural practices (HCDA 2005). The government partnering with USAID and major exporters conducts pest surveillance inspections on small green bean farms. USAID has also funded capacity building in local government certification agencies through staff training and establishment of pathogen and pesticide residue testing facilities that can bring down the costs of certification for the smallholders. Further, USAID funding has also facilitated partnership between Kenya Horticultural Development Project (KHDP) and green bean exporters. The partnership provides management and business skills training and market advisory services. 
Donors and NGOs have also jointly established Africa's only indigenous certification company aimed at making EUREPGAP certification cheaper and hence accessible to smallholders. A PPP between UK Department for International Development (DFID) and HCDA (Horticultural Crops Development Authority) has trained a pool of export horticulture service providers. Three NGOs (namely, Care International (Kenya), Reach the Children Inc, and ICIPE) are partnering with the private firms to train, audit, and/or financially help smallholders to obtain EUREPGAP certification. Most of these NGOs are supported by donor agencies. In addition, ICIPE is currently partnering with green bean exporters (e.g., Kenya Horticultural Exporters and Woni) to train EUREPGAP trainers and other horticultural industry service providers. Reach the Children Inc. has activities that involve 10 smallholder farmer groups in Machakos. The activities include EUREPGAP certification, training in good agricultural practices, micro-credit services, and market linkage program.

Another NGO, Pride Africa, works on creating linkages between various actors in the horticultural industry aimed at i) training on good agricultural practices and access to technical information; ii) access to credit; and iii) access to the export market. It has facilitated linkages between farmer groups and EUREPGAP trainers, input sellers, banks, and exporters. The Pride Africa-Donor partnership facilitates smallholders access to credit needed to finance IFSS investments and transition from old to new but often costly pesticides. Pride Africa is sponsored by international donors including IDRC, IFAD, and FORD Foundation. The Pesticide Initiative Program, a European Union funded project run by the Liaison Committee for Europe, Africa, Caribbean, and Pacific (COLEACP), supports capacity building among green bean exporters.

\section{Compliance with standards by the Mahagrapes farmers through collective action and $\mathrm{PPP}^{14}$}

Mahagrapes has enabled farmers in several ways to ensure their compliance with IFSS. Kleinwechter and Grethe (2005), while analyzing the adoption of EUREPGAP standards by mango exporters in Peru, differentiate the compliance process into three stages: the information stage followed by a decision stage, followed subsequently by an implementation stage. Mahagrapes and the cooperatives have been active in all the three stages of the compliance process. Even before the actual creation of Mahagrapes, efforts were made by some of the leading and educated farmers of the region to involve the numerous pre-existing grape growing farmer

\footnotetext{
14 This section is from Roy and Thorat (2006)
} 
groups under the umbrella of Mahagrapes. In order to convince the group leaders, a team of seven people: five farmers, one scientist, and one government official visited Europe to see for themselves how grape farming, processing, and marketing was done along with the nature and form of inputs used and marketing methods followed. A part of the cost of this visit was funded by the state government. These lead farmers were convinced that the grape produced by the farmers was of quality good enough to be exported to Europe provided they could meet the standards and safety regulations, and thus Mahagrapes came to be set up.

Mahagrapes holds workshops where information on the standards is disseminated to the member farmers. Farmers and grape handlers/sorters (primarily women) are continuously informed about and trained in the latest grape growing and handling methods and processes. The cooperatives and Mahagrapes jointly update the list of banned and approved pesticides and fertilizers continuously, which varies with time and across markets. Similarly, the changes in the permissible levels of chemical residues are also provided by them regularly. All this information is published in the form of a yearly handbook in the native language and distributed free of charge to members. In addition, acquiring a EUREPGAP certificate individually is costly for the small and medium grape farmers. However, Mahagrapes has managed to provide cooperatives with this certification. Thus, member farmers now have to pay just Rs. 1200 (approximately \$28) for certification which is much less than the cost of individual membership.

Once the information on the standards is available, action is needed relating to the decision on implementation. In the implementation stage, Mahagrapes provides materials and technical help along with infrastructural support to facilitate the implementation of the standards. Similar to the Kenyan case, some farmers are trained as technical experts and ensure that implementation of production practices satisfies the FSS. Mahagrapes also provides the farmers with packaging material which comply with international norms. Plastic bags and pallets in which the grapes are first packed are imported from Spain and other places. Special sulphur dioxide sheets are imported from China. In the purchase of inputs, the role of CA presents itself quite distinctly. The production and marketing process requires several imported inputs where the differences in prices for farmers because of bulk buying by cooperatives are substantial.15 Bio-

\footnotetext{
${ }^{15}$ Most significant input from the point of view of cost reduction through CA is the case of bio-fertilizers from Australia
} 
fertilizer and bio-pesticide are developed and produced by Mahagrapes and provided to member farmers cheaper than market rates.16

Apart from CA on the part of farmers that has made farmers well informed about the market requirements and has facilitated lower costs of production, partnerships with public agencies have played a very important role. For example, regular monitoring of the grape plant by the scientists from the National Research Centre (NRC) in Pune (a government agency) ensures that the plant remains in sanitary condition throughout the year and not just in the fruiting season.

Also, during the initial time periods with high rates of rejection, the role played by the government was critical. The role of the government over time has been akin to infant industry protection and thereby is a good example of PPP. State bodies like Maharashtra State Agricultural Marketing Board (MSAMB) deputed and paid the salaries of the first governing officers. MSAMAB also provided funds for consultancy services from experts on agri-marketing, packaging, and technical services such as refrigeration and cooling. The government body, National Cooperative Development Commission (NCDC), was also of great help along with Agriculture and Processed Food Products Export Development Authority (APEDA), and National Horticulture Board. The agency provided subsidized credit for the installation of post harvest facilities that were crucial in bringing down the consignment rejection rates substantially. 17 Cooperatives linked with Mahagrapes with partial financial aid from the state government and partial self-financing have installed pre-coolers and cold storages at all the 16 cooperative headquarters (thus showing CA and PPPs in complementary roles).

\section{Absence of collective action and PPP in the cantaloupe supply chain in Mexico's}

In Mexico, for the smallholders export was the main reason they went into cantaloupe production, and just a small share of the production earlier was sent to domestic market. After a new regulation, small growers turned to the domestic market. In the domestic market, smallholders also face a problem with poor technical support and low prices during the harvesting season of cantaloupes. Currently, most technical support is provided by the inputs suppliers, but

\footnotetext{
${ }^{16}$ These inputs are also sold to non-members but at higher prices, implying cross-subsidization.

${ }^{17}$ In the early years of exports, consignment rejection rates were greater than 80 percent. At present the Mahagrapes claims a negligible rate of rejection. The turnaround by Mahagrapes especially in light of the struggle by Indian horticultural exports to meet the standards in the western markets makes an exciting case study from a food safety and quality point of view.

${ }^{18}$ This section is from Avendaño et al., forthcoming
} 
only 38 percent of the smallholders receive this type of assistance (from survey of farmers in north-western Mexico in 2002). In the growing season, oversupply is a problem; 44 percent of the Mexican production is in the summer, from the states of Durango, Coahuila, Chihuahua Tamaulipas (Northern Mexico), and for the rest of the regions the growing season is in winter. Low prices and the lack of certification on food safety restrict the options for the small growers. In the survey, smallholders reported that it is not economical for them to absorb the additional cost associated with FSS, and they lacked the skills to keep the registers; they also need training and additional employees for the design of standard operations procedures. In the survey, 71 percent of farmers had adopted some new food safety practices (Avendaño 2006). Of this group, 9 percent were small farmers, 54 percent were medium, and 37 percent were large. Of the non-adopters, 14 percent were small and 86 percent were medium. Another obstacle for smallholders was the lack of administrative management; 90 percent of the small growers hardly know their costs associated with production, and they do not keep accounting registers and do not plan production in advance. Lack of management practices can be explained partly as a result of the low educational level among farmers. About 60 percent farmers have primary education (6 years); 13 percent have secondary (9 years), and only 15 percent high school (11 years).

Apart from collective action that can help farmers establish packing facilities together and afford the certification costs, PPPs can also play an important role. One form of CA and PPP that can be useful is the organization of growers in an integrated firm that allows them to buy at greater scale with better prices. Growers and government together like in case of Kenyan green beans and grapes in India should develop a program to comply with IFSS. PPPs could also be useful in supporting research and development activities targeted to the needs of smallholders. Such partnerships can be encouraged through institutional agreements between government and universities in the region. Cooperation among farmers and partnership with government can facilitate the installation of a new packing facility run by small growers.

Training is also needed in this stage through Food Safety certification where PPP can be employed. A PPP can be established to assure cold chain, either through jointly owned cold storage or by renting some facilities that can be controlled to keep the quality demanded by markets. Similarly, a PPP could be established with the purpose of enabling smallholders to achieve certifications such as EUREPGAP required by the markets. The roles of such forms of CA and PPPs are along the lines discussed in the success cases discussed above. 


\section{CONCLUSIONS}

This paper focuses on the access of smallholders to markets with high demands for standards related to food safety and quality. We presented three case-studies: green beans in Kenya, grapes in India, and cantaloupes in Mexico. These products at different times have faced food safety-related barriers, and it has been a challenge to re-orient the production and marketing systems to meet the market demands within a system inclusive of the smallholders. The Mexican cantaloupe case is distinguished by the screening of the smallholders away from the high standards market. The coping mechanism for the smallholders has either been a movement towards different crop or shifting the production of cantaloupe towards domestic markets that require lower standards.

The examples of the Kenyan green beans and the Indian grapes point to successful cases of smallholder participation in high standard markets. In Kenya, though a number of smallholders survived in the fresh beans exports, there was a definite adjustment in the form of moving towards production for the beans canning industry which had lower food safety demands. In the Indian grapes case, the initial periods when the organization started exporting were characterized by extremely high rates of rejection; many cooperatives consisting of smallholders de-linked themselves from the export markets. Those producer organizations that stayed have over time achieved much greater ability to meet the standards, and as reflected in the negligible rates of rejections at present. However, the inability of the smallholders to adjust to IFSS shocks in the short run comes out as the common message. In Mexico, after the imposition of the regulation, the short run response has been to screen the smallholders away.

What do these case studies imply for sustainability of smallholder dominated systems in high standard markets and the role of CA and PPP? In the Mexico case, there has been an absence of any forms of CA and PPP; in addition, little time has elapsed since the IFSS shock occurred. In the Kenyan green beans case as well as the case of grape exports from India, the role of CA and PPP are clearly identified. However in both these cases, the results were borne out over the long run.

Alternatively, vertical coordination (like contract farming) where some of the costs are delegated away to the integrator can help sustain smallholders in IFSS based system. Yet the role of CA surfaces in this system on two grounds. First, contract farming with a large number of 
smallholders involves high transaction costs. Hence, farmer groups become a useful means of reducing these linkage costs. Indeed, in contract farming with small farmers, the working system has been a vendor type set up where a group of farmers collectively link to a vendor who in turn links up with the firm. This type of arrangement is evident in the Kenya beans case where contract growing has been adopted. Secondly, the role of collective action is desirable for boosting bargaining power for a group of smallholders. One straightforward way for this channel to work is by farmer groups handling marketing themselves or with a marketing partner and bypassing the intermediaries (as the case of Mahagrapes shows).

Even though the role of PPPs is important for creating market access for small farmers, the role of the government should be supplementary to the private sector as a partner to strengthen the asset base and enable risk-taking by insuring in the short run as the smallholders cope with the demands of high standard markets. IFSS bring high returns with high risk especially in times when the response systems have not matured. The government has a role to correct specific market failures in the chain but not to protect the chain itself. The reason we emphasize the role of PPPs in this context is that the Kenyan and Indian examples do show that smallholders, given time and initial support, can participate in IFSS markets successfully. Indeed, these supply chains are very knowledge intensive, and some enabling factors like knowledge about technology and markets are required for smallholders to participate in high value chains. Thus, though we emphasize the role of fixed costs and the consequent scale diseconomies, investments in capacity building of the smallholders (especially in their ability to meet standards) where private returns are much lower than social returns have to be undertaken by the public sector, possibly in partnership with the private sector. 


\section{REFERENCES}

ANTAD. 2005. Tendencias en México, actitudes del consumidor y el Supermercado. México. (Consumer and supermarkets attitudes, Tendencies in Mexico).

Avendaño, B, C. Narrod, M. Tiongco. Food safety requirements in Latin American cantaloupe exports and their impact on Small Farmers. IFPRI Discussion Paper. Forthcoming.

Avendaño, B. et al.. 2006, La inocuidad alimentaria en México. Las hortalizas frescas de exportacion. Universidad Autonoma de Baja California-Miguel Angel Porrua Editor-H. Cámara de Diputados LIX Legislatura, México.

Bardhan P. and J. Dayton-Johnson. 2002. Inequality and conservation of the local Commons: a theoretical exercise. The Economic Journal 112 (481). 577-602

Baron, D. 1978. Why cooperation in agricultural marketing? Journal of Agricultural Economics 29:109-16

Bienabe, E. and D. Sautier. 2005. The role of small scale producer's organizations to address market access, Paper presented at the International Seminar Beyond Agriculture: Making Markets Work for the Poor, London, UK, 28 Feb.-1 Mar.

Calvin, L. 2003. Produce, Food safety, and international trade: Response to U.S. foodborne illness outbreaks associated with imported produce. In International trade and food safety: Economic theory and case studies, ed. Buzby, J. USDA, Econ. Res. Serv., AER-828.

Calvin, L., W. Foster, L. Solorzano, J. D. Mooney, L. Flores, and V. Barrios. 2002. Response to a food safety problem in produce: A case study of a Cyclosporiasis outbreak. In Global food trade and consumer demand for quality, ed. Krissoff, B., M. Bohman, and J. Caswell. New York: Kluwer Academic/Plenum Publishers.

Collins, J.L. 1995. Farm size and non traditional exports: Determinants of participation in world markets. World Development 23(1995) 1103-1114.

Debertin, D. L. Agricultural production economics. 2nd ed, privately published, 1992 (CD-ROM, 2002).

Dolan, C. and J. Humphrey. 2000. Governance and trade in Fresh vegetables: The Impact of UK supermarkets on African horticultural industries. Journal of Development Studies 37:147177.

Dolan, C, J. Humphrey, and C. Harris-Pascal. 1999. Horticulture Commodity Chains: The impact of UK markets on African fresh Vegetable Industry. Working Paper 96. Institute of Development Studies, University of Sussex, UK.

Dong, F. and H. Jensen. 2004. The challenge of conforming to sanitary and phytosanitary measures for China's agricultural exports, Midwest Agribusiness Trade Research and Information Center (MATRIC), Iowa State University Working Paper 04MWP-8 
Food and Agriculture Organization (FAO) 2005. Agricultural data, FAOSTAT, Food and Agriculture Organization of the United Nations.

Food and Drug Administration (FDA). 2007. Import detention reports. Available at http://www.fda.gov/ora/oasis/ora_oasis_ref.html

Freidberg, S. 2005. Unsustainable booms and enduring busts: The cultural economy of African agriculture. Draft.

Freidberg, S. 2004. French beans and food scares: Culture and commerce in an anxious age. New York: Oxford University Press.

Freidberg, S. 2003. The contradictions of clean: The supermarket ethical trade and African horticulture. Gatekeeper Series. No. 109. Available at www.iied.org/NR/agbioliv/gatekeepers/documents/GK109.pdf

Hatanaka, M., C. Bain. And L. Busch, 2005. Third-party certification in the global agri-food system. Food Policy, 30:354-369.

Henson, S. O. Masakure, and D. Boselie. 2005. Private food safety and quality standards for fresh producer exporters: The case of Hortico Agrisystems, Zimbabwe. Food Policy 30: 371-384.

Henson, S. and N. H. Hooker. 2001. Private Sector Management of Food Safety: Public Regulation and the Role of Private Controls. In special issue of The International Food and Agribusiness Management Review. Private Sector Management of Food Safety. 4(1)

Henson, S., T. Reardon. 2005. Private agri-food standards: Implications for food policy and the agri-food system. Food Policy, 30:241-253.

Humphrey, J. 2003. Paper presented at FAO symposium on the state of agriculture commodity market research. Rome.

Humphrey, J. 2005. Shaping value chains for development: Global value chains in agribusiness, Paper written for the Deutsche Gesellschaft fur Technische Zusammenarbeit (GTZ).

Jaffee, S. 2003. From challenge to opportunity: Transforming Kenya's fresh vegetable trade in the context of emerging food safety and other standards in Europe. Agriculture and Rural Development Discussion Paper No. 2. Washington, D.C.: World Bank

Jaffee, S. and O. Masakure. 2005. Strategic use of private standards to enhance international competitiveness: Vegetable exports from Kenya and elsewhere. Food Policy 30: 316333.

Jaffee S and J Morton 1995. Private sector high-value food processing and marketing: A synthesis of African experience. In Marketing Africa's high-value foods: Comparative experiences of an emergent private sector, ed. Jaffee, S. and J. Morton. Dubuque, Iowa: Kendall/Hunt

Jensen, M. F. (n.d) Food safety requirements and smallholders: A case study of Kenyan fresh produce exports. The Royal Veterinary and Agricultural University. Unpublished. 
Kant S. 2000, A dynamic approach to forest regimes in developing economies. Ecological Economics 32, 287-300

Kaplinsky, R. and M. Morris. 2001. A Handbook for value chain research. http://sds.ukzn.ac.za/files/handbook_valuechainresearch.pdf

Kimenye, L.N. 1993. Economics of smallholder french bean production and marketing in Kenya. PhD Dissertation, Michigan State University.

Kleinwechter. U. and H. Grethe 2005. The significance of food quality and safety standards in developing countries - A case study for the Eurepgap standard in the mango export sector in Piura, Peru. Poster at the Deutscher Tropentag 2005, Hohenheim, Germany.

Lam, W. F. 1998. Governing irrigation systems in Nepal: Institutions, infrastructure, and collective action. Oakland, CA: Institute for Contemporary Studies Press

Loader, R. and J. E. Hobbs 1999. Strategic responses to food safety legislation, Food Policy 24 (6): 685-706.

Maharashtra Agriculture Produce Marketing (Regulation) Act. 1963. Maharashtra Cooperative act. Available as Government of Maharashtra document

Minot N. and D. Roy. 2006. Impact of High value agriculture and modern marketing channels on poverty: A conceptual framework. Washington D.C.: International Food Policy Research Institute. Mimeo.

Mehta, R. and J. George. 2005. Food safety regulation concerns and trade: A developing country perspective. New Delhi, India: MacMillan India, Ltd.

Narrod, C., A. Gulati, N. Minot and C. Delgado. 2005. Food safety research priorities for the CGIAR -A draft concept note from IFPRI for the Science Council, Washington D.C.: International Food Policy Research Institute.

Okello, J. 2005. Compliance with international food safety standards: The case of green bean production in Kenyan family farms. PhD Dissertation, Michigan State University.

Okello, J., C. Narrod, D. Roy. Forthcoming. Food safety requirements in African green bean exports and their impact on small farmers. IFPRI working paper. Washington, D.C.: International Food Policy Research Institute.

Poulton C. 2005. Presentation made at the The future of small farms. Research Workshop (IFPRI, ODI and Imperial College)—June, 26-29, 2005 Withersdane Conference Centre, Wye, UK

Ranade, C. Agricultural cooperatives in India. Seminar presented at. Dept. of Agricultural Economics, Michigan State University, Oct. 26.

Reardon, T. C. Timmer, C. Barrett, and J. Berdegue. 2003. The rise of supermarkets in Africa, Asia, and Latin America, American Journal of Agricultural Economics 5: 1142.

Reardon, T and Julio Berdegue 2002. The rapid rise of supermarkets in Latin America: Challenges and opportunities for development. Development Policy Review 20 (4): 371388. 
Rich, K.M. and C. A. Narrod. 2005. Perspectives on supply chain management of high value agriculture: The role of public-private partnerships in promoting smallholder access. Draft.

Roy D. and A. Thorat. 2006. Small they may be, Indian Farmers they are but export they can: The Case of Mahagrapes farmers in India. Washington, D.C.: International Food Policy Research Institute. Mimeo.

Singh, B.P. 2002. Nontraditional crop production in Africa for export. In Trends in new crops and new uses, ed. Janick, J. and A. Whipkey. Alexandria, VA: ASHS Press.

Staatz, John M. 1984. A theoretical perspective on the behavior of farmers. Ph.D. dissertation, Michigan State University.

Umali-Deininger D. and M. Sur, 2006. Food safety in a globalizing world: Opportunities and challenges for India. Paper presented at the International Association of Agricultural Economists Conference, Gold Coast Australia, August

Unnevehr, L. 2000. Food safety issues and fresh food product exports form LDC. Agricultural Economics 23: 231-240.

Wilkins, P.C. 1983. Marketing, farm supply cooperatives serve more than half United States farmers. Farmer Cooperatives January: 12-13

World Bank. 2005. From competition at home to competing abroad: The case of Indian horticulture, Washington, D.C.: World Bank. Mimeo

World Bank. 2006. China's compliance with food safety requirements for fruits and vegetables: Promoting food safety, competitiveness and poverty reduction, Washington, D.C./Beijing: World Bank.

http://siteresources.worldbank.org/INTRANETTRADE/Resources/Topics/Standards/CHI NA Jan06part1.pdf 


\section{List of CAPRi Working Papers}

01 Property Rights, Collective Action and Technologies for Natural Resource Management: A Conceptual Framework, by Anna Knox, Ruth Meinzen-Dick, and Peter Hazell, October 1998.

02 Assessing the Relationships between Property Rights and Technology Adoption in Smallholder Agriculture: A Review of Issues and Empirical Methods, by Frank Place and Brent Swallow, April 2000.

03 Impact of Land Tenure and Socioeconomic Factors on Mountain Terrace Maintenance in Yemen, by A. Aw-Hassan, M. Alsanabani and A. Bamatraf, July 2000.

04 Land Tenurial Systems and the Adoption of a Mucuna Planted Fallow in the Derived Savannas of West Africa, by Victor M. Manyong and Victorin A. Houndékon, July 2000.

05 Collective Action in Space: Assessing How Collective Action Varies Across an African Landscape, by Brent M. Swallow, Justine Wangila, Woudyalew Mulatu, Onyango Okello, and Nancy McCarthy, July 2000.

06 Land Tenure and the Adoption of Agricultural Technology in Haiti, by Glenn R. Smucker, T. Anderson White, and Michael Bannister, October 2000.

07 Collective Action in Ant Control, by Helle Munk Ravnborg, Ana Milena de la Cruz, María Del Pilar Guerrero, and Olaf Westermann, October 2000.

08 CAPRi Technical Workshop on Watershed Management Institutions: A Summary Paper, by Anna Knox and Subodh Gupta, October 2000.

09 The Role of Tenure in the Management of Trees at the Community Level: Theoretical and Empirical Analyses from Uganda and Malawi, by Frank Place and Keijiro Otsuka November 2000.

10 Collective Action and the Intensification of Cattle-Feeding Techniques a Village Case Study in Kenya's Coast Province, by Kimberly Swallow, November 2000.

11 Collective Action, Property Rights, and Devolution of Natural Resource Management: Exchange of Knowledge and Implications for Policy, by Anna Knox and Ruth Meinzen-Dick, January 2001.

12 Land Dispute Resolution in Mozambique: Evidence and Institutions of Agroforestry Technology Adoption, by John Unruh, January 2001.

13 Between Market Failure, Policy Failure, and "Community Failure": Property Rights, CropLivestock Conflicts and the Adoption of Sustainable Land Use Practices in the Dry Area of Sri Lanka, by Regina Birner and Hasantha Gunaweera, March 2001. 
14 Land Inheritance and Schooling in Matrilineal Societies: Evidence from Sumatra, by Agnes Quisumbing and Keijuro Otsuka, May 2001.

15 Tribes, State, and Technology Adoption in Arid Land Management, Syria, by Rae, J, Arab, G., Nordblom, T., Jani, K., and Gintzburger, G., June 2001.

16 The Effects of Scales, Flows, and Filters on Property Rights and Collective Action in Watershed Management, by Brent M. Swallow, Dennis P. Garrity, and Meine van Noordwijk, July 2001.

17 Evaluating Watershed Management Projects, by John Kerr and Kimberly Chung, August 2001.

18 Rethinking Rehabilitation: Socio-Ecology of Tanks and Water Harvesting in Rajasthan, NorthWest India, by Tushaar Shah and K.V.Raju, September 2001.

19 User Participation in Watershed Management and Research, by Nancy Johnson, Helle Munk Ravnborg, Olaf Westermann, and Kirsten Probst, September 2001.

20 Collective Action for Water Harvesting Irrigation in the Lerman-Chapala Basin, Mexico, by Christopher A. Scott and Paul Silva-Ochoa, October 2001.

21 Land Redistribution, Tenure Insecurity, and Intensity of Production: A Study of Farm Households in Southern Ethiopia, by Stein Holden and Hailu Yohannes, October 2001.

22 Legal Pluralism and Dynamic Property Rights, by Ruth Meinzen-Dick and Rajendra Pradhan, January 2002.

23 International Conference on Policy and Institutional Options for the Management of Rangelands in Dry Areas, by Tidiane Ngaido, Nancy McCarthy, and Monica Di Gregorio, January 2002.

24 Climatic Variablity and Cooperation in Rangeland Management: A Case Study From Niger, by Nancy McCarthy and Jean-Paul Vanderlinden, September 2002.

25 Assessing the Factors Underlying the Differences in Group Performance: Methodological Issues and Empirical Findings from the Highlands of Central Kenya, by Frank Place, Gatarwa Kariuki, Justine Wangila, Patti Kristjanson, Adolf Makauki, and Jessica Ndubi, November 2002.

26 The Importance of Social Capital in Colombian Rural Agro-Enterprises, by Nancy Johnson, Ruth Suarez, and Mark Lundy, November 2002.

27 Cooperation, Collective Action and Natural Resources Management in Burkina Faso: A Methodological Note, by Nancy McCarthy, Céline Dutilly-Diané, and Boureima Drabo, December 2002.

28 Understanding, Measuring and Utilizing Social Capital: Clarifying Concepts and Presenting a Field Application from India, by Anirudh Krishna, January 2003. 
29 In Pursuit Of Comparable Concepts and Data, about Collective Action, by Amy Poteete And Elinor Ostrom, March 2003.

30 Methods of Consensus Building for Community Based Fisheries Management in Bangladesh and the Mekong Delta, by Parvin Sultana and Paul Thompson, May 2003.

31 Formal and Informal Systems in Support of Farmer Management of Agrobiodiversity: Some Policy Challenges to Consolidate Lessons Learned, by Marie Byström, March 2004.

32 What Do People Bring Into the Game: Experiments in the Field About Cooperation in the Commons, by Juan-Camilo Cárdenas and Elinor Ostrom, June 2004.

33 Methods for Studying Collective Action in Rural Development, by Ruth Meinzen-Dick, Monica Di Gregorio, and Nancy McCarthy, July 2004.

34 The Relationship between Collective Action and Intensification of Livestock Production: The Case of Northeastern Burkina Faso, by Nancy McCarthy, August 2004.

35 The Transformation of Property Rights in Kenya's Maasailand: Triggers and Motivations by Esther Mwangi, January 2005.

36 Farmers' Rights and Protection of Traditional Agricultural Knowledge, by Stephen B. Brush, January 2005.

37 Between Conservationism, Eco-Populism and Developmentalism - Discourses in Biodiversity Policy in Thailand and Indonesia, by Heidi Wittmer and Regina Birner, January 2005.

38 Collective Action for the Conservation of On-Farm Genetic Diversity in a Center of Crop Diversity: An Assessment of the Role of Traditional Farmers' Networks, by Lone B. Badstue, Mauricio R. Bellon, Julien Berthaud, Alejandro Ramírez, Dagoberto Flores, Xóchitl Juárez, and Fabiola Ramírez, May 2005.

39 Institutional Innovations Towards Gender Equity in Agrobiodiversity Management: Collective Action in Kerala, South India,, by Martina Aruna Padmanabhan, June 2005.

40 The Voracious Appetites of Public versus Private Property: A View of Intellectual Property and Biodiversity from Legal Pluralism, by Melanie G. Wiber, July 2005.

41 Who Knows, Who Cares? Determinants of Enactment, Awareness and Compliance with Community Natural Resource Management Bylaws in Uganda, by Ephraim Nkonya, John Pender, Edward Kato, Samuel Mugarura, and James Muwonge, August 2005.

42 Localizing Demand and Supply of Environmental Services: Interactions with Property Rights, Collective Action and the Welfare of the Poor, by Brent Swallow, Ruth Meinzen-Dick, and Meine von Noordjwik, September 2005. 
43 Initiatives for Rural Development through Collective Action: The Case of Household Participation in Group Activities in the Highlands of Central Kenya, By Gatarwa Kariuki and Frank Place, September 2005.

44 Are There Customary Rights to Plants? An Inquiry among the Baganda (Uganda), with Special Attention to Gender, by Patricia L. Howard and Gorettie Nabanoga, October 2005.

45 On Protecting Farmers' New Varieties: New Approaches to Rights on Collective Innovations in Plant Genetic Resources by Rene Salazar, Niels P. Louwaars, and Bert Visser, January 2006.

46 Subdividing the Commons: The Politics of Property Rights Transformation in Kenya's Maasailand, by Esther Mwangi, January 2006.

47 Biting the Bullet: How to Secure Access to Drylands Resources for Multiple Users, by Esther Mwangi and Stephan Dohrn, January 2006.

48 Property Rights and the Management of Animal Genetic Resources, by Simon Anderson and Roberta Centonze, February 2006.

49 From the Conservation of Genetic Diversity to the Promotion of Quality Foodstuff: Can the French Model of 'Appellation d'Origine Contrôlée' be Exported? by Valérie Boisvert, April 2006.

50 Facilitating Collective Action and Enhancing Local Knowledge: A Herbal Medicine Case Study in Talaandig Communities, Philippines, by Herlina Hartanto and Cecil Valmores, April 2006.

51 Water, Women and Local Social Organization in the Western Kenya Highlands, by Elizabeth Were, Brent Swallow, and Jessica Roy, July 2006.

52 The Many Meanings of Collective Action: Lessons on Enhancing Gender Inclusion and Equity in Watershed Management, by Laura German, Hailemichael Taye, Sarah Charamila, Tesema Tolera, and Joseph Tanui, July 2006.

53 Decentralization and Environmental Conservation: Gender Effects from Participation in Joint Forest Management, by Arun Agrawal, Gautam Yadama, Raul Andrade, and Ajoy Bhattacharya, July 2006.

54 Improving the Effectiveness of Collective Action: Sharing Experiences from Community Forestry in Nepal, by Krishna P. Achyara and Popular Gentle, July 2006.

55 Groups, Networks, and Social Capital in the Philippine Communities, by Marie Godquin and Agnes R. Quisumbing, October 2006.

56 Collective Action in Plant Genetic Resources Management: Gendered Rules of Reputation, Trust and Reciprocity in Kerala, India, by Martina Aruna Padmanabhan, October 2006. 
57 Gender and Local Floodplain Management Institutions--A case study from Bangladesh, by Parvin Sultana and Paul Thompson, October 2006.

58 Gender Differences in Mobilization for Collective Action: Case Studies of Villages in Northern Nigeria, by Saratu Abdulwahid, October 2006.

59 Gender, Social Capital and Information Exchange in Rural Uganda, by Enid Katungi, Svetlana Edmeades, and Melinda Smale, October 2006.

60 Rural Institutions and Producer Organizations in Imperfect Markets: Experiences from Producer Marketing Groups in Semi-Arid Eastern Kenya, by Bekele Shiferaw, Gideon Obare and Geoffrey Muricho, November 2006.

61 Women's Collective Action and Sustainable Water Management: Case of SEWA's Water Campaign in Gujarat, India, by Smita Mishra Panda, October 2006.

62 Could Payments for Environmental Services Improve Rangeland Management inCentral Asia, West Asia and North Africa? by Celine Dutilly-Diane, Nancy McCarthy, Francis Turkelboom, Adriana Bruggeman, James Tiedemann, Kenneth Street and Gianluca Serra, January 2007.

63 Empowerment through Technology: Gender Dimensions of Social Capital Build-Up in Maharashtra, India, by Ravula Padmaja and Cynthia Bantilan, February 2007.

64 Gender and Collective Action: A Conceptual Framework for Analysis, by Lauren Pandolfelli, Ruth Meinzen-Dick, and Stephan Dohrn, May 2007.

65 Gender, Wealth, and Participation in Community Groups in Meru Central District, Kenya, by Kristin E. Davis and Martha Negash, May 2007.

66 Beyond Group Ranch Subdivision: Collective Action for Livestock Mobility, Ecological Viability, and Livelihoods, by Shauna BurnSilver and Esther Mwangi, June 2007.

67 Farmer Organization, Collective Action and Market Access in Meso-America, by Jon Hellin, Mark Lundy, and Madelon Meijer, October 2007.

68 Collective Action for Innovation and Small Farmer Market Access: The Papa Andina Experience, by André Devaux, Claudio Velasco, Gastón López, Thomas Bernet, Miguel Ordinola, Hernán Pico, Graham Thiele, and Douglas Horton, October 2007.

69 Collective Action and Marketing of Underutilized Plant Species: The Case of Minor Millets in Kolli Hills, Tamil Nadu, India, by Guillaume P. Gruère, Latha Nagarajan, and E.D.I. Oliver King, M.S. Swaminathan Research Foundation, October 2007. 